\title{
Geology of Part of the Nelchina River Gabbronorite and Associated Rocks, South-Central Alaska
}

\section{U.S. GEOLOGICAL SURVEY BULLETIN 2058}

Prepared in cooperation with the

Alaska Division of Geological and Geophysical Surveys

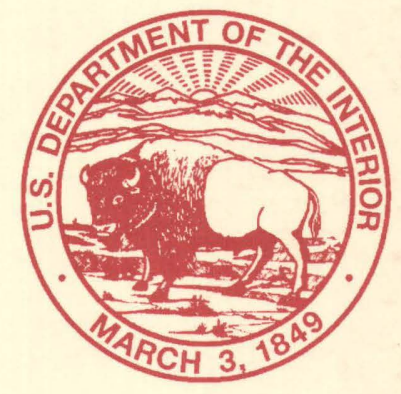





\section{Geology of Part of the Nelchina River Gabbronorite and Associated Rocks, South-Central Alaska}

By Laurel E. Burns

U.S. GEOLOGICAL SURVEY BULLETIN 2058

Prepared in cooperation with the

Alaska Division of Geological and Geophysical Surveys

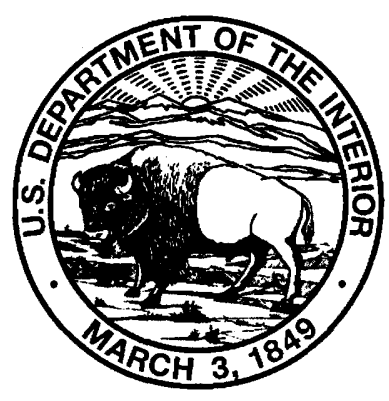

UNITED STATES GOVERNMENT PRINTING OFFICE, WASHINGTON : 1996 


\title{
U.S. DEPARTMENT OF THE INTERIOR BRUCE BABBITT, Secretary
}

\author{
U.S. GEOLOGICAL SURVEY \\ Gordon P. Eaton, Director
}

\author{
For sale by \\ U.S. Geological Survey, Information Services \\ Box 25286, Federal Center \\ Denver, CO 80225
}

\begin{abstract}
Any use of trade, product, or firm names in this publication is for descriptive purposes only and does not imply endorsement by the U.S. Government

Text edited by Andrea Eddy and Jeff Troll

Illustrations edited by Andrea Eddy and Dale Russell;

prepared by Nancy Hoskin, Carol Quesenberry, and Steve Scott
\end{abstract}

\section{Library of Congress-in-Publication Data}

Burns, L.E.

Geology of part of the Nelchina River Gabbronorite and associated rocks, south-central Alaska / by Laurel E. Burns ; prepared in cooperation with the Alaska Division of Geological and Geophysical Surveys.

p. cm. -- (U.S. Geological Survey bulletin ; 2058)

Includes bibliographical references.

1. Gabbro--Alaska--Nelchina River Region. 2. Rocks, Igneous--Alaska--Nelchina River Region. I. Alaska. Division of Geological and Geophysical Surveys. II. Title. III. Series.

QE75.B9 no. 2058

[QE462.G3]

557.3 s--dc20

[552' .3] 


\section{CONTENTS}

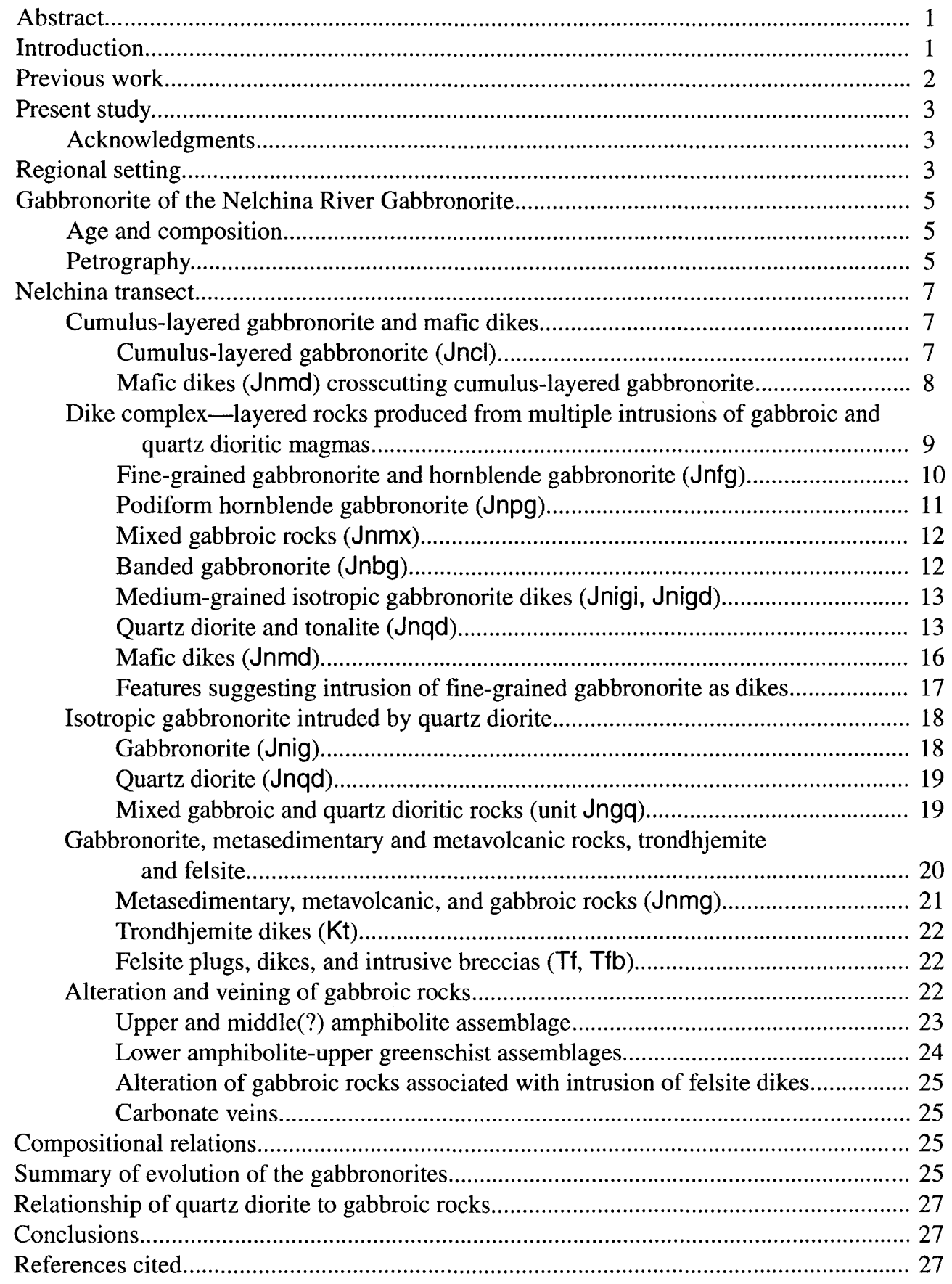




\section{PLATES}

[Plates are in pocket]

1. Bedrock geologic map of the Nelchina River Gabbronorite near Nelchina Glacier, south-central Alaska.

2. Major alteration of the Nelchina River Gabbronorite near Nelchina Glacier, south-central Alaska.

\section{FIGURES}

1. Generalized geologic map of south-central Alaska showing location of the Nelchina River Gabbronorite .1

2. Detailed location map showing Nelchina transect (type locality for the Nelchina River Gabbronorite) and reference localities.

3. Generalized geologic map of Nelchina transect, showing major lithologic groups in the Nelchina River Gabbronorite.

4. Photograph showing fine-scale modal-mineral and phase layers in gabbronorite............................................................

5. Photograph showing flow foliation and plastic deformation of gabbronorite and fine-grained mafic dike...........................9

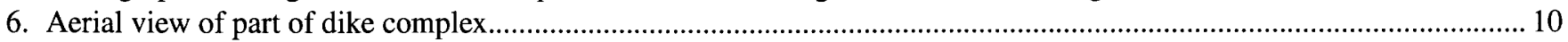

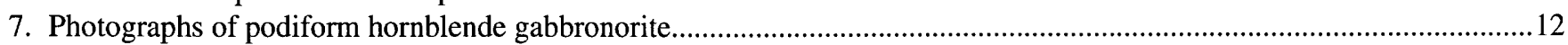

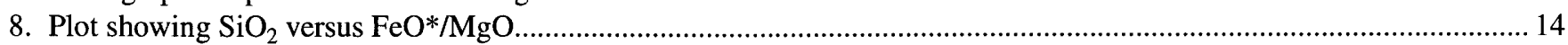

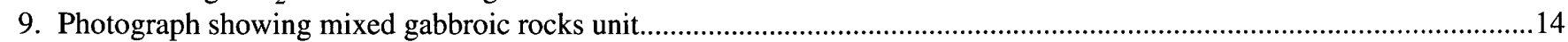

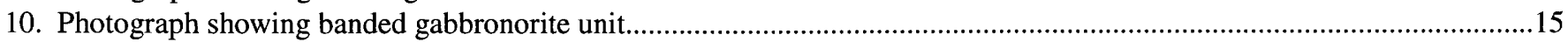

11. Detailed geologic map showing gabbronorite dike (Jnigd) intruding podiform hornblende gabbronorite unit (Jnpg).......16

12-17. Photographs showing:

12. Gabbronorite dike (Jnigi) with recognizable inclusions of podiform hornblende gabbronorite unit (Jnpg) ......................17

13. Quartz diorite pluton containing abundant ovoid and stretched xenoliths of gabbronorite................................................ 18

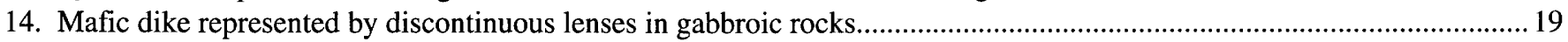

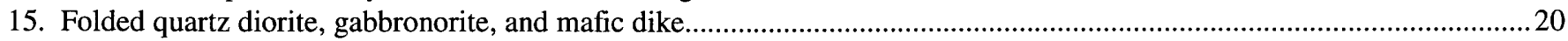

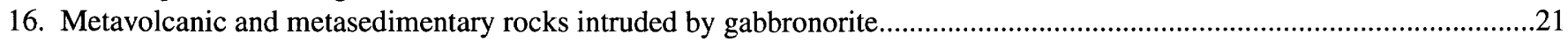

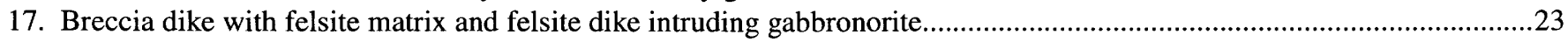

18. Chart showing major assemblages in gabbroic rocks from Nelchina transect..................................................................24

19. AFM ternary diagram of gabbroic rocks from the Nelchina River Gabbronorite ..............................................................26

\section{TABLES}

1. Major-oxide chemical analyses of and CIPW norms for gabbroic rocks, mafic dikes, quartz diorites, trondhjemites, and felsites from the Nelchina River Gabbronorite.

2. Mole fractions $\mathrm{Mg} /\left(\mathrm{Mg}+\mathrm{Fe}^{*}\right)$ for coexisting orthopyroxene and cummingtonite/anthophyllite 


\title{
GEOLOGY OF PART OF THE NELCHINA RIVER GABBRONORITE AND ASSOCIATED ROCKS, SOUTH- CENTRAL ALASKA
}

\author{
By Laurel E. Burns ${ }^{1}$
}

\begin{abstract}
The Nelchina River Gabbronorite forms the largest mass in a discontinuous elongate zone of fault-bounded bodies composed dominantly of mafic and ultramafic plutonic rocks in south-central Alaska. The mafic and ultramafic rocks within this zone have been interpreted to be the fractional-crystallization products of a hydrous basaltic magma that produced basaltic and andesitic volcanic rocks. Minor quartz diorite, tonalite, granodiorite, and metasedimentary and metavolcanic rocks are intrusively and tectonically mixed with the mafic and ultramafic rocks and form an integral part of the Nelchina River Gabbronorite. The relationship of these subordinate rocks to the gabbroic rocks has not been clearly understood by previous workers. Detailed geologic mapping, petrographic study, and geochemical analyalong a glacially polished strip of rocks - the Nelchina transect-leads to the following observations and conclusions of relevance to the origins of island-arc plutonic rocks. (1) Some of the gabbroic layering formed by in situ crystallization, whereas other layering formed by multiple injection of gabbroic magma effectively producing a coarse-grained sheeted-dike (or sill) complex. (2) Although the dike complex displays features generally attributed to classic layered sequences-such as size-graded layers, phase contacts, and wispy layeringthe field relationships observed in the Nelchina transect indicate that these features formed as a result of multiple intrusion and flow foliation. (3) Textures of the metasedimentary and metavolcanic rocks that are intruded by the gabbroic rocks are typical of those produced by deep-seated (catazonal) intrusions. This observation indicates crystallization at pressures of at least
\end{abstract}

\footnotetext{
${ }^{1}$ Present address: Alaska Division of Geological and Geophysical Surveys, 794 University Ave., Suite 200, Fairbanks, Alaska 99709.
}

Manuscript approved for publication February 11, 1993.
3 to $10 \mathrm{kbar}(300-1,000 \mathrm{mPa})$, or about 10 to $30 \mathrm{~km}$ depthon the basis of mineral compositions of the Nelchina River Gabbronorite and the nearby, related Tonsina ultramaficmafic assemblage. (4) Plastic-deformation textures in both the gabbroic rocks and the quartz diorite-tonalite suggest that quartz diorite and tonalite magmas intruded while the gabbroic rocks were still warm though probably after most of the gabbroic intrusions were emplaced. The plastic-deformation textures significantly constrain both the assigned age of the gabbroic rocks and interpretation of processes of formation of arc complexes in general.

\section{INTRODUCTION}

The Nelchina River Gabbronorite (described and formally named herein) consists dominantly of gabbronorite (two-pyroxene gabbro) of Early to Middle Jurassic age with minor ultramafic rocks, quartz diorite, tonalite, granodiorite, and metasedimentary and metavolcanic rocks. The Nelchina River Gabbronorite (equivalent to the Nelchina Complex of Burns, 1985) forms the largest mass (170 km long by $2-10 \mathrm{~km}$ wide) in a discontinuous elongate zone of fault-bounded bodies, composed dominantly of mafic and ultramafic plutonic rocks and known as the Border Ranges ultramafic and mafic complex (Burns, 1985), which crops out discontinuously from Kodiak Island to near Tonsina. These rocks crop out in the southern part of the Peninsular terrane in south-central Alaska (fig. 1). Field relationships, petrologic and compositional data, and geochronology suggest that these mafic-ultramafic rocks, including the Nelchina River Gabbronorite, are part of the plutonic core of an intraoceanic island arc of Early to Middle Jurassic age and its associated metamorphic rocks (Burns, 1985). The mafic-ultramafic rocks appear to be genetically related to the andesitic volcanic rocks that crop out farther north and probably represent the fractional crystallization product associated with these andesitic volcanic rocks (Burns, 1985; Newberry and others, 1986). 
This report describes the geology of a 6-km by $0.3-$ $\mathrm{km}$ strip of glacially polished rocks of the Nelchina River Gabbronorite (figs. 1; locality C, fig. 2; pl. 1). The strip is located in the eastern part of the Anchorage $(1: 250,000)$ quadrangle along the west edges of secs. 29 and 32, T. 1 S., R. 10 W., and secs. 5 and 8, T. 2 S., R. 10 W., of the Anchorage C-1 $(1: 63,360)$ quadrangle. This strip is situated along the west side of the valley of the Nelchina River and adjacent to the lateral moraine. These nearly continuous exposures, referred to herein as the "Nelchina transect," effectively constitute a cross section through the northern Chugach Mountains. The transect, shown as the three contiguous areas $a, b$, and c on plate 1 , is herein designated as the type locality for the Nelchina River Gabbronorite. The glacially polished outcrops along the Nelchina transect reveal textures and contact relations that are invaluable for understanding the processes that formed the gabbronorite body.

\section{PREVIOUS WORK}

Geologic mapping of the Nelchina River Gabbronorite was largely of reconnaissance nature prior to the present

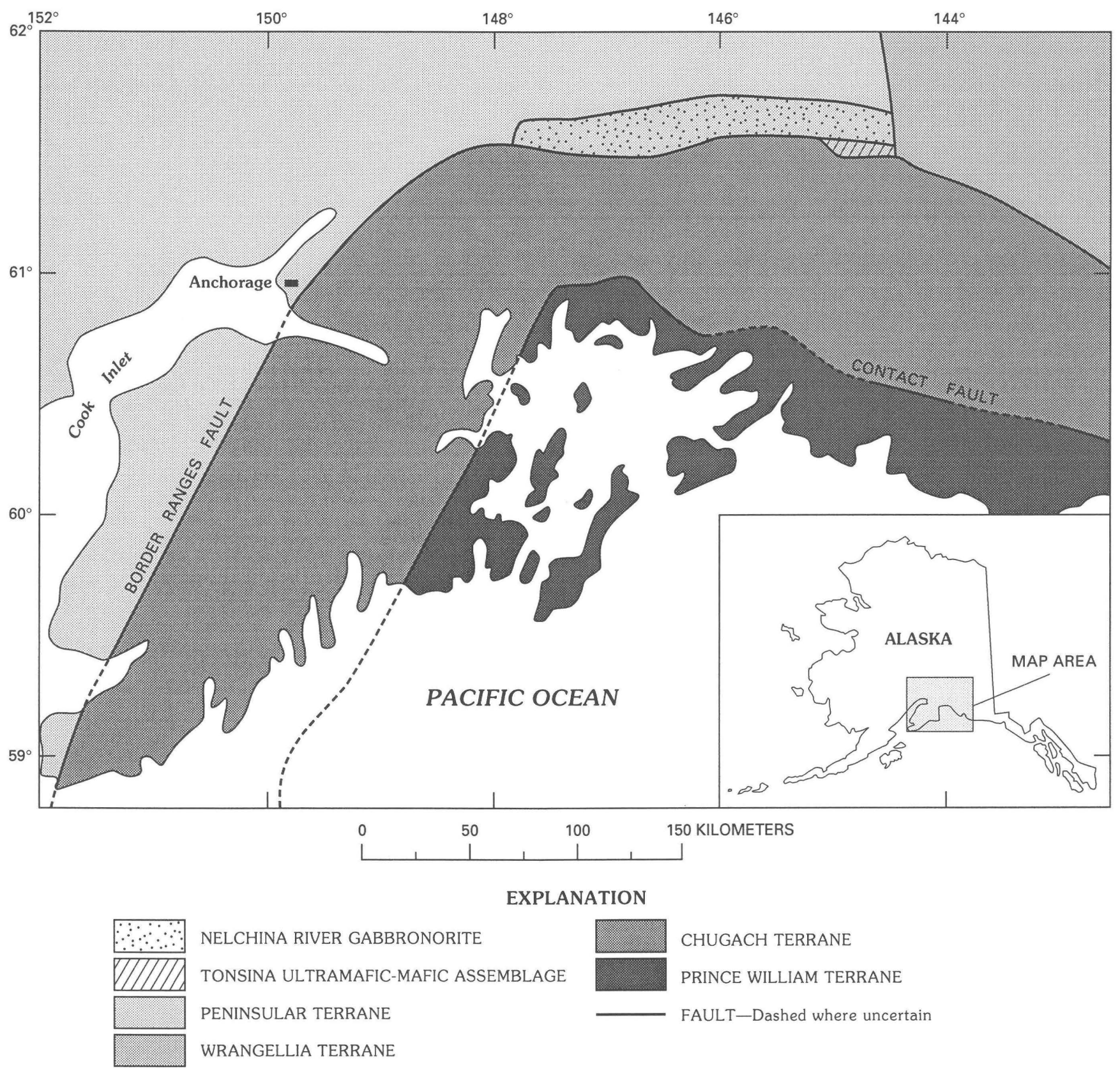

Figure 1. Generalized geologic map of part of south-central Alaska showing approximate location of the Nelchina River Gabbronorite and the Tonsina ultramafic-mafic assemblage. Modified from Plafker and others (1977). 
study. During reconnaissance mapping, Grantz (1960; $1961 \mathrm{a}, \mathrm{b} ; 1965)$ and Andreason and others (1964) noted the existence of plutonic rocks of intermediate composition along with minor amounts of gabbroic rocks in the north-central Chugach Mountains.

The presence of a large body of mafic plutonic rocks in the Nelchina River area was not known until 1979-80 when Winkler and others (1981) and Pessel and others (1981) mapped portions of the body at scales of $1: 250,000$ and 1:63,360, respectively. Burns and others (1983) mapped the western part of the body in the northeastern Anchorage quadrangle at a scale of 1:25,000. Burns (1983) described aspects of the Nelchina River Gabbronorite not presented in this paper. Burns (1985) summarized and interpreted the geology of the mafic-ultramafic rocks along the northern Chugach Mountains.

Published aeromagnetic studies of the area include the 1:250,000-scale Valdez quadrangle (U.S. Geological Survey, 1979) and part of the northern part of the 1:250,000-scale Anchorage quadrangle (Alaska Division of Geological and Geophysical Surveys, 1973); aeromagnetic maps $(1: 250,000)$ with interpretations include those of Andreason and others (1964) and Case and others (1985). Gravity maps (1:250,000 and smaller scale) of this area were published by Andreason and others (1964), Barnes (1977), and Burns (1982). Burns (1982) also included both aeromagnetic and gravity modeling of the Nelchina River Gabbronorite.

\section{PRESENT STUDY}

The description of the type section of the Nelchina River Gabbronorite in this paper results from three summers of regional geologic mapping at 1:25,000 scale of the Nelchina River Gabbronorite (1979-80, 1982), including helicopter time to view and map different parts of the Border Ranges ultramafic and mafic complex, and one summer of detailed geologic mapping at 1:2400 scale of the Nelchina transect (1981). Twenty-six rocks were analyzed for major-oxide compositional data and about 300 thin sections from the Nelchina River Gabbronorite were examined petrographically to determine the petrology and mineralogy of the body.

\section{ACKNOWLEDGMENTS}

Three funding agencies supported the field and lab work that made the present study possible. The Alaska Division of Geological and Geophysical Surveys (ADGGS) provided support for the four summers of field geologic map- ping (1979-82). Additional helicopter time was supplied by Gary Winkler of the U.S. Geological Survey (USGS) as part of the Alaska Mineral Resource Assessment Program (AMRAP) of the Anchorage and Valdez quadrangles. The major-element geochemical analyses of 26 rocks were performed by the ADGGS laboratory. About 300 thin sections were provided by the ADGGS and the USGS. Funding for microprobe analyses was provided by National Science Foundation grants EAR80-01076 and EAR8115522 through N.H. Sleep of Stanford University.

The criticisms of R.G. Coleman, J.G. Liou, R.J. Newberry, G.H. Pessel, J.E. Case, N.H. Sleep, R.R. Compton, N.J Page, and A.B. Ford are gratefully acknowledged. A.C. Eddy provided excellent editorial comments. Assistance from S.M. Stone and J.R. Le Compte on nomenclature proved very helpful. G.H. Pessel, J.C. Pessel, and K.S. Emmel plane-tabled the topographic map of the area.

\section{REGIONAL SETTING}

The east-west trending Nelchina River Gabbronorite crops out along the north edge of the Chugach Mountains in the southern part of the Peninsular terrane (figs. 1,2); it overlaps the northeastern part of the Anchorage quadrangle and the northern part of the Valdez quadrangle.

Although Quaternary alluvium largely covers the eastern half of the body, geologic mapping and aeromagnetic data indicate that gabbroic rocks are present from near Tonsina to the Matanuska Glacier, a total distance of $170 \mathrm{~km}$ (Pessel and others, 1981; Winkler and others, 1981; Burns, 1982; Burns and others, 1983). The western part of the Nelchina River Gabbronorite, from Tazlina Lake to the Matanuska Glacier, is well exposed. The body appears to be everywhere fault bounded; no intrusions of gabbroic rocks are present in surrounding rocks.

The Nelchina River Gabbronorite is herein named for the Nelchina River; its type locality is designated as the previously described Nelchina transect (see "Introduction"). The unit is composed dominantly of various types of gabbronorite with lesser quartz diorite, tonalite, granodiorite, and ultramafic, metasedimentary, and metavolcanic rocks. The gabbronorites and the quartz diorite, tonalite, and granodiorite intruding the gabbronorite are considered Early to Middle Jurassic in age (Winkler and others, 1981). The metavolcanic and metasedimentary rocks are clearly older than the plutonic rocks, but their protolith ages are uncertain. These metamorphic rocks show some similarity to the Pennsylvanian and Permian Skolai Group (MacKevett, 1976) to the east and the rocks of Early Jurassic metamorphic age described by Carden and Decker (1977) near the Eklutna Complex. Minor amounts of Cretaceous(?) trondhjemite and Tertiary felsite intrude the 


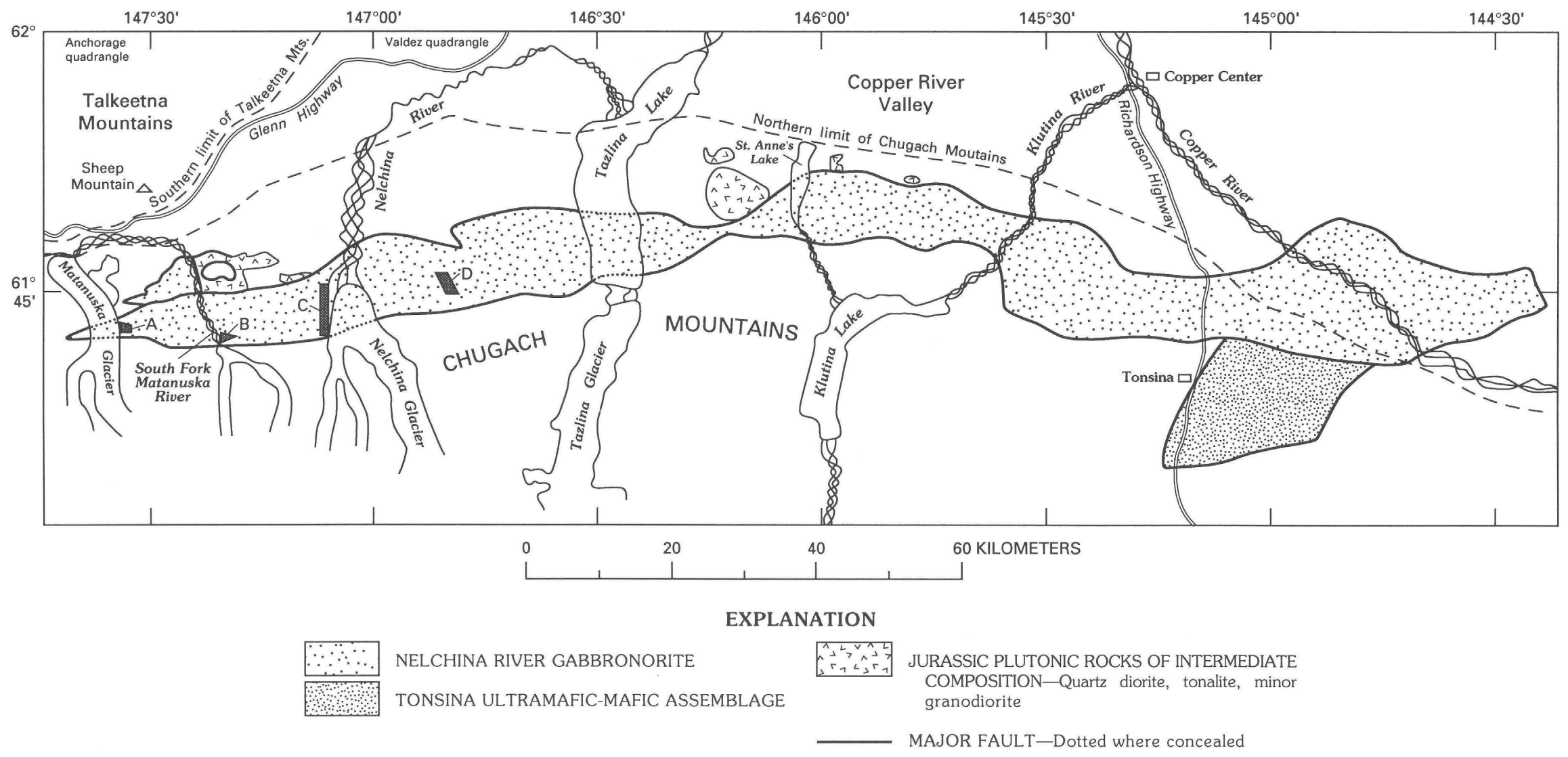

Figure 2. Detailed location map showing the Nelchina River Gabbronorite, the Tonsina ultramafic-mafic assemblage, Jurassic plutonic rocks of intermediate composition, and major faults. $A$, Reference locality for dikes of quartz diorite and trondhjemite intruding gabbronorite east of the Matanuska Glacier; $B$, reference locality for metasedimentary and metavolcanic rocks intruded by minor gabbroic rocks; $C$, Nelchina transect, type locality for the Nelchina River Gabbronorite; and $D$, reference locality for the Barnette Creek section of cumulus-layered gabbronorite. Modified from Winkler and others (1981), Pessel and others (1981), and Burns and others (1983). 
Nelchina River Gabbronorite. The Nelchina River Gabbronorite is thus regarded as Jurassic in age.

A reference locality for the cumulus-layered gabbronorite of the Nelchina River Gabbronorite, a ridge where no quartz diorite or metasedimentary rocks are present (Burns, 1983), is situated east of Barnette Creek in the Valdez quadrangle (locality D, fig. 2). Within T. 1 S, R. 9 W. of the Valdez D-8 quadrangle $(1: 63,360)$, the ridge trends southeastward from the southeast corner of sec. 22 and continues through the corner of sec. 23 and across sec. 26. A reference locality for gabbroic rocks intruded by dikes of quartz diorite and trondhjemite is present east of the Matanuska Glacier in the Anchorage C-2 quadrangle $(1: 63,360)$ at the boundaries between secs. 25 and 36, T. 19 N., R. 10 E., and between secs. 30 and 31, T. 19 N., R. 11 E. The dike rocks crop out on both sides of an east-west-trending creek (locality A, fig. 2) and are shown as a distinct unit on the map by Burns and others (1983). A reference locality for the metamorphic rocks is also present in the Anchorage C-1 quadrangle $(1: 63,360)$ in the SE $1 / 4$ sec. 32 , T. 19 N., R. 12 E. (locality B, fig. 2). This outcrop is a glacier-polished strip on the east side of the South Fork of the Matanuska River; these metamorphic rocks are shown as a distinct map unit by Pessel and others (1981).

On the north, the Nelchina River Gabbronorite is fault bounded against quartz diorite, tonalite, and minor granodiorite of Jurassic age and against andesitic volcanic rocks of the Lower Jurassic Talkeetna Formation (Pessel and others, 1981; Winkler and others, 1981; Burns and others, 1983). Barker and Grantz (1982) concluded that the Talkeetna Formation represents the volcanic part of an intraoceanic island arc on the basis of major-oxide and trace-element compositional data. The quartz diorite and tonalite intrude the Talkeetna Formation as well as the gabbronorite of the Nelchina River Gabbronorite.

To the south, the Nelchina River Gabbronorite is generally fault bounded against the McHugh Complex by a Tertiary high-angle fault. The McHugh Complex is a subduction complex with an accretion age of mid(?)- Cretaceous and a protolith age of Jurassic and Cretaceous (Plafker and others, 1985). The McHugh Complex in this area is a chaotic mixture of massive greenstone, chert, pillow basalt, graywacke, and argillite (Winkler and others, 1981). Some of the Tertiary high-angle faulting has locally placed the Valdez Group (a Late Cretaceous accretionary wedge) against the south margin of the Nelchina River Gabbronorite (Pessel and others, 1981; Burns and others, 1983). The Valdez Group consists primarily of metasandstone, metasiltstone, and argillite (Clark, 1972).

The easternmost part of the Nelchina River Gabbronorite is faulted against the Wrangellia terrane of Jones and others (1981) (Winkler and others, 1981); the westernmost part pinches out between two crosscutting high-angle Tertiary faults (Burns and others, 1983).

\section{GABBRONORITE OF THE NELCHINA RIVER GABBRONORITE}

\section{AGE AND COMPOSITION}

The Nelchina River Gabbronorite includes layered and massive gabbronorite, magnetite gabbronorite (with greater than 5 percent primary iron-titanium oxide), and leucogabbronorite (with 65-90 percent calcic plagioclase). (Lithologic terminology is that of Streckeisen (1976) with the exception that pyroxene-hornblende gabbronorite is herein called hornblende gabbronorite.) No further distinction is made between gabbronorite and magnetite gabbronorite in this report because of highly variable amounts of magnetite over small areas. Anorthosite, hornblende gabbronorite, and leuconorite are also present; gabbro and olivine-bearing gabbro are extremely rare. Serpentinized ultramafic rocks, generally wehrlite, troctolite, and chrome-bearing dunite, are volumetrically very minor but are present in discontinuous fault slices near the south edge of the Nelchina River Gabbronorite. Dikes and small plutons of quartz diorite, tonalite, and trondhjemite are abundant in the Nelchina River Gabbronorite but are commonly too small to depict on regional geologic maps (for example, Burns and others, 1983).

Potassium-argon dating of quartz diorites and related rocks in the north-central Chugach Mountains yields ages of 188 to $165 \mathrm{Ma}$ (Winkler and others, 1981; Pavlis, 1982). These ages are about the same as potassium-argon ages on hornblende from the Nelchina River Gabbronorite and from a klippe of gabbroic rocks to the south (see Winkler and others, 1981). Five potassium-argon ages on hornblende and one on clinopyroxene from five gabbroic rock samples range from 188 to $154 \mathrm{Ma}$ (Winkler and others, 1981). Only one of these five ages is younger than 166 Ma. Two older potassium-argon hornblende ages, 419 and $267 \mathrm{Ma}$ (Winkler and others, 1981), are probably caused by excess argon. Field relationships discussed in this report suggest that the intermediate plutonic rocks and the mafic-ultramafic rocks are, in part, contemporaneous, and thus the bulk of the gabbroic rocks are probably Early to Middle Jurassic in age.

\section{PETROGRAPHY}

Because many of the gabbroic rocks on the Nelchina transect are highly altered, a brief description of the unaltered gabbroic rocks of the Nelchina River Gabbronorite follows. A more detailed discussion of the gabbroic rocks is found in Burns (1983).

In the typical gabbronorite of the Nelchina River Gabbronorite, plagioclase is commonly unzoned or only 


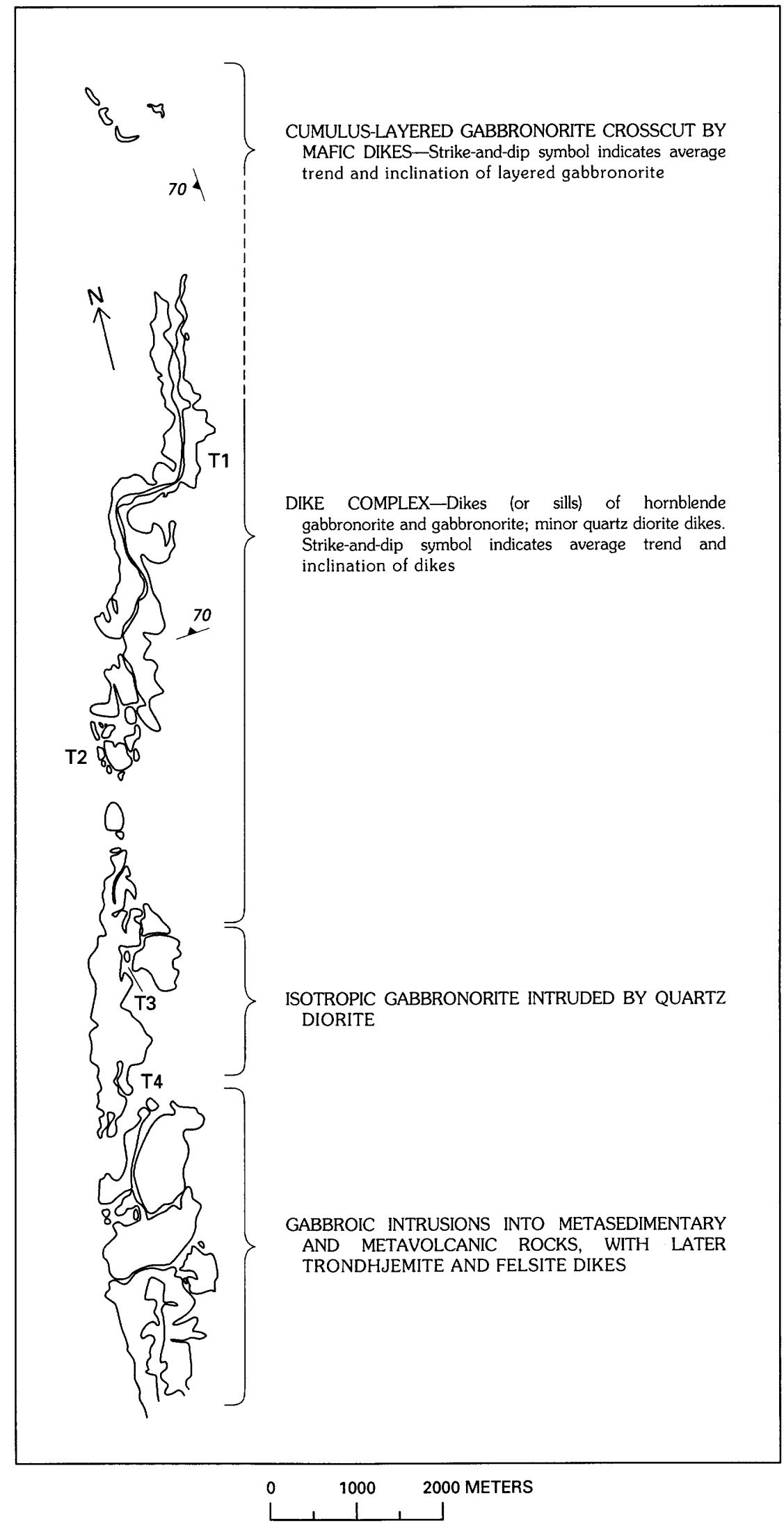

Figure 3. Diagrammatic representation of Nelchina transect of the Nelchina River Gabbronorite, showing four major lithologic groups and reference locations $\mathrm{T} 1$ to $\mathrm{T} 4$ (see text). Brackets are dashed where transition between lithologic groupings is uncertain. 
slightly zoned. Plagioclase composition within most of the body ranges from $\mathrm{An}_{65}$ to $\mathrm{An}_{95}$ (Burns, 1983). Orthopyroxene is ubiquitous and is about equal to clinopyroxene in abundance. Orthopyroxene typically exhibits pink-green pleochroism; optical and limited microprobe data suggest compositions of approximately $\mathrm{En}_{63-77} \mathrm{Fs}_{21.5-37} \mathrm{Wo}_{0-1.5}$. Thin clinopyroxene exsolution lamellae are common in most orthopyroxenes. Electron microprobe analyses given elsewhere (Burns, 1983, 1985) indicate that the clinopyroxene crystals are diopside, salite, and calcic augite. Thin orthopyroxene exsolution lamellae are present in about half of the clinopyroxene crystals.

Most hornblende in the gabbroic rocks is pargasitic and is pale greenish tan to light brown. The pargasitic hornblende typically forms less than 5 percent of the rock and is most common as reaction rims around clinopyroxene. The pargasitic hornblende is inferred to be a late-magmatic phase or the result of high-temperature reequilibration that took place shortly after crystallization.

Gabbronorites containing 10 to 40 percent magnesiohornblende are present on the Nelchina transect and in the western part of the Nelchina River Gabbronorite. These rocks are discussed in detail in this paper.

Primary magnetite and ilmenite are common in the gabbronorites and magnetite gabbronorites of the Nelchina River Gabbronorite. Modal abundance of magnetite and ilmenite ranges from 0 to 15 percent, but most gabbronorites contain from 2 to 6 percent opaque minerals. The presence of thin lamellae of ilmenite in magnetite suggests oxidation exsolution.

Deuteric-alteration assemblages are ubiquitous in the Nelchina River Gabbronorite. The alteration appears to have encompassed a wide range of temperatures and suggests slow cooling of the gabbroic rocks. Mineral compositions and assemblages of the rocks composing the Nelchina River Gabbronorite suggest reequilibration at temperatures similar to granulite through lower amphibolite-upper greenschist conditions (Burns, 1983). The rocks in the Nelchina transect largely contain amphibolite and greenschist assemblages (see section "Alteration and Veining of Gabbroic Rocks").

\section{NELCHINA TRANSECT}

Four major lithologic groups of the Nelchina River Gabbronorite were mapped in the Nelchina transect (fig. 3 ; pl. 1). From north to south these are (1) cumulus-layered gabbronorite and mafic dikes, (2) dike-complex rocks (layered rocks produced by multiple intrusions of gabbroic and quartz dioritic magmas), (3) isotropic gabbronorite intruded by quartz diorite, and (4) gabbroic intrusive rocks and their metasedimentary and metavolcanic host rocks with later trondhjemite and felsite dikes. Extensive deformation, alteration, and veining are superimposed on the
Nelchina River Gabbronorite (pls. 1 and 2). However, numerous areas of less-altered gabbroic rocks, common preservation of primary mineral textures, and detailed studies of pyroxene-alteration products permit the determination of original rock types. The four different major lithologic groups are described below; map-unit symbols given in parentheses are from plate 1 .

\section{CUMULUS-LAYERED GABBRONORITE AND MAFIC DIKES}

\section{CUMULUS-LAYERED GABBRONORITE (JnCl)}

Cumulus layers composed dominantly of rustyweathering gabbronorite crop out at the north end of the Nelchina transect (fig. 3). [The terms "cumulus," "adcumulus," and "mesocumulus" are used in this report in the sense of Irvine (1982) as textural terms suggesting only that the rock formed by fractional crystallization; they are not meant to imply formation by crystal settling in a magma chamber.] Layers defined by significant modal variations in orthopyroxene, clinopyroxene, and plagioclase are as much as $5 \mathrm{~m}$ in thickness. Fine-scale phase and modally graded layers, 1 to $3 \mathrm{~cm}$ thick, are also common (fig. 4). Anorthosite layers $1 \mathrm{~cm}$ wide are abundant. The thin layers are lens-shaped in cross section with a typical width of less than $10 \mathrm{~m}$. Erosional unconformities, scour channels, and graded beds-considered typical of crystal settlings and magmatic currents-are not present among the layers.

The gabbronorites have mesocumulus to adcumulus textures and contain 15 to 30 percent orthopyroxene (ferrobronzite-hypersthene?), 15 to 30 percent clinopyroxene (augite), and 40 to 65 percent slightly zoned calcic plagioclase (bytownite). Both pyroxenes have abundant, fine exsolution lamellae of pyroxenes. Amphibole (probably magnesiohornblende, pargasite, or varieties of pargasitic hornblende) forms roughly 10 percent of the rock and is pale greenish tan in thin section. The hornblende forms thick rims on clinopyroxene crystals, narrow rims on orthopyroxene crystals, and abundant, optically continuous blebs within clinopyroxene crystals. Minor amounts of interstitial magnetite and ilmenite are common in the gabbronorites.

Alteration in the gabbronorites probably occurred during two periods. The earlier, higher temperature phase affected many of the gabbronorites in the Nelchina River Gabbronorite; this presumably deuteric alteration is characterized by the formation of cummingtonite/anthophyllite, fine-grained magnetite from orthopyroxene, and minor clinozoisite from plagioclase. At lower temperatures, actinolite (apparently magnesium rich on the basis of its pale color) and magnetite formed from clinopyroxene. Actinolite is absent from most of the mas- 
sive and cumulus-layered gabbronorites elsewhere in the Nelchina River Gabbronorite; its presence in the transect suggests that these cumulus-layered gabbronorites had more low-temperature alteration than is typical elsewhere in the formation.

Most of the cumulus-layered gabbronorites in the transect are characterized by two types of deformation textures. The earliest deformation produced bent plagioclase and pyroxene crystals and thus probably occurred at moderate temperatures. Formation of all secondary fibrous amphiboles appears to have occurred after the early deformation as indicated by unfractured actinolite and cummingtonite/anthophyllite present in the previously bent pyroxene crystals. Later, brittle deformation produced fractured plagioclase grains, broken fibrous amphiboles, and abundant deformation lamellae in pyroxenes. Such textures typify the gabbronorite from areas where massive, brittle deformation occurred (Burns and others, 1983).

\section{MAFIC DIKES (Jnmd) CROSSCUTTING CUMULUS-LAYERED GABBRONORITE}

At least two generations of fine-grained mafic dikes crosscut the cumulus-layered gabbronorite. The dikes of both generations appear to have the same mineralogy. The dikes are composed of fine-grained primary hornblende and plagioclase. The plagioclase is zoned, has a bimodal grain-size distribution, and is relatively unaltered. Optical methods indicate a plagioclase composition of $\mathrm{An}_{50-60}$. Cores of some of the larger plagioclase crystals were probably more calcic but are now altered to clinozoisite and epidote. Overgrowth by secondary albite(?) on the edges of the zoned plagioclase crystals is common. Hornblende in the dikes is green to greenish tan and is generally present as subhedral crystals. Magnetite and ilmenite typically compose 5 to 10 percent of the rock and are present as interstitial anhedral clots and as subhedral crystals. Re-

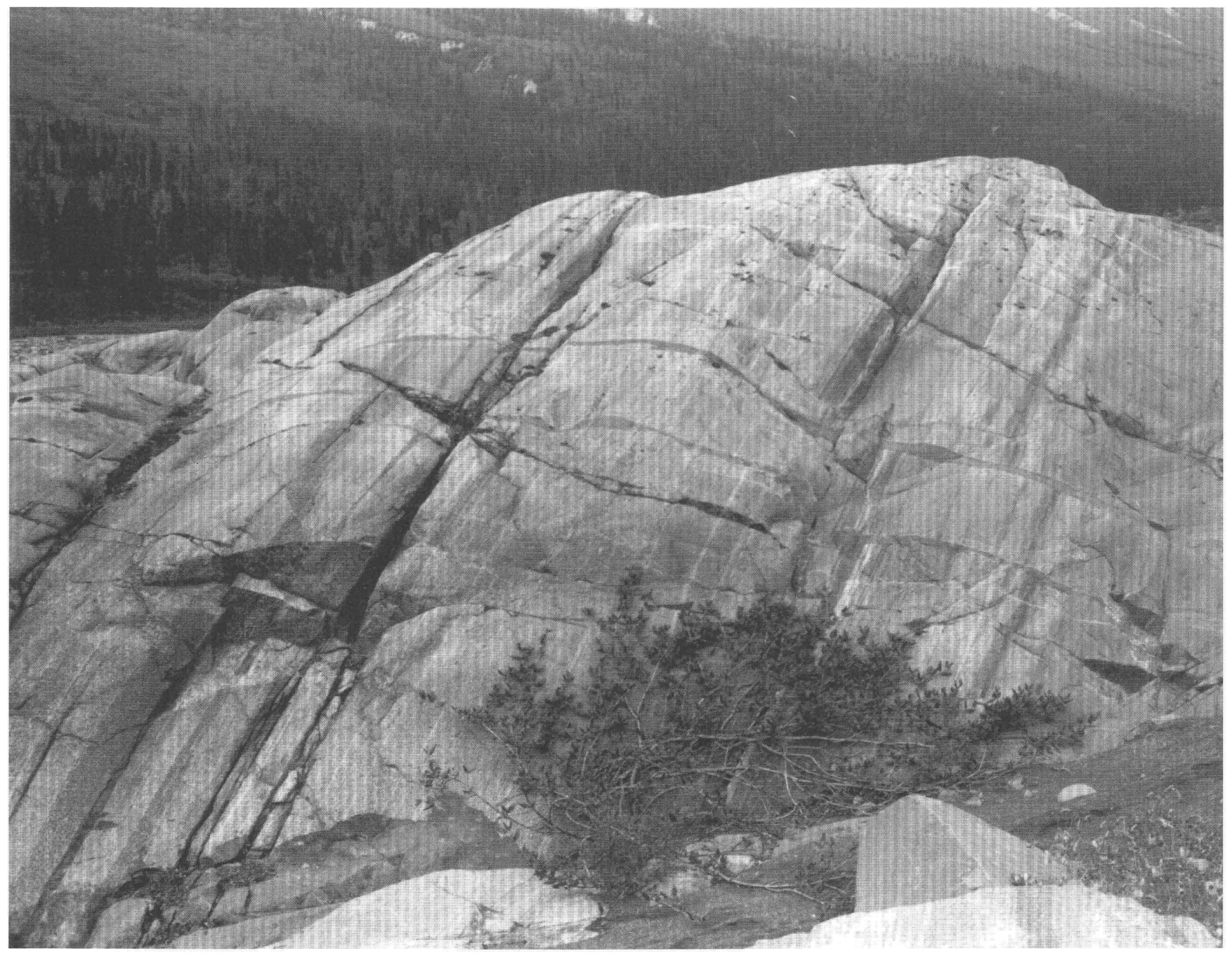

Figure 4. Fine-scale phase and modally graded layers defined by variations in pyroxenes and (or) plagioclase, in cumulus-layered gabbronorite, north end of transect. Narrow mafic dikes crosscut layering; minor offset across dikes is common. Outcrop is $5.5 \mathrm{~m}$ wide. View to northwest. Photograph by G.H. Pessel. 
placement of these oxides by pyrite is common. Minor amounts of quartz are present in a few of the dikes.

The dikes showing effects of plastic deformation (fig. 5) and flow banding are inferred to have intruded as part of the earlier generation. Near the margins of these dikes, the layering of the host gabbroic rock is similarly deformed, apparently by intrusion of the dikes (fig. 5). The early deformation textures seen in thin section in the gabbronorite probably resulted from intrusion of the dikes, as the bent pyroxene and plagioclase crystals suggest ductile behavior of the crystals at moderate temperatures. The layered gabbronorite must have been close to solidus temperatures when the mafic dikes intruded. Also, pargasitic(?) hornblende in these gabbronorites is more abundant than is typical of other gabbronorites of the Nelchina River Gabbronorite; its abundance suggests an addition of water at an early stage of the cooling history of the gabbronorite. The plastically deformed hornblende gabbro dikes may have been the source for the early water or may have been conduits for the water that formed the relatively abundant hornblende in the gabbronorites.
Other fine-grained mafic dikes in this area do not show effects of plastic deformation and are thought to have intruded when the gabbroic rocks were relatively cool. Intrusion of the dikes may have contributed to the gabbronorites' brittle deformation evident in such textural features as fractured plagioclase and cummingtoniteanthophyllite crystals (see section "Cumulus-Layered Gabbronorite"). The intrusions of these dikes may also have induced the formation of the abundant actinolite in the surrounding gabbronorite. Small $(0.5 \mathrm{~m})$, right- and left-lateral offsets in layering across the dikes are common (fig. 4).

\section{DIKE COMPLEX-LAYERED ROCKS PRO. DUCED FROM MULTIPLE INTRUSIONS OF GABBROIC AND QUARTZ DIORITIC MAGMAS}

Layered rocks produced by multiple sheet intrusions of gabbronorite, hornblende gabbronorite, and quartz di-

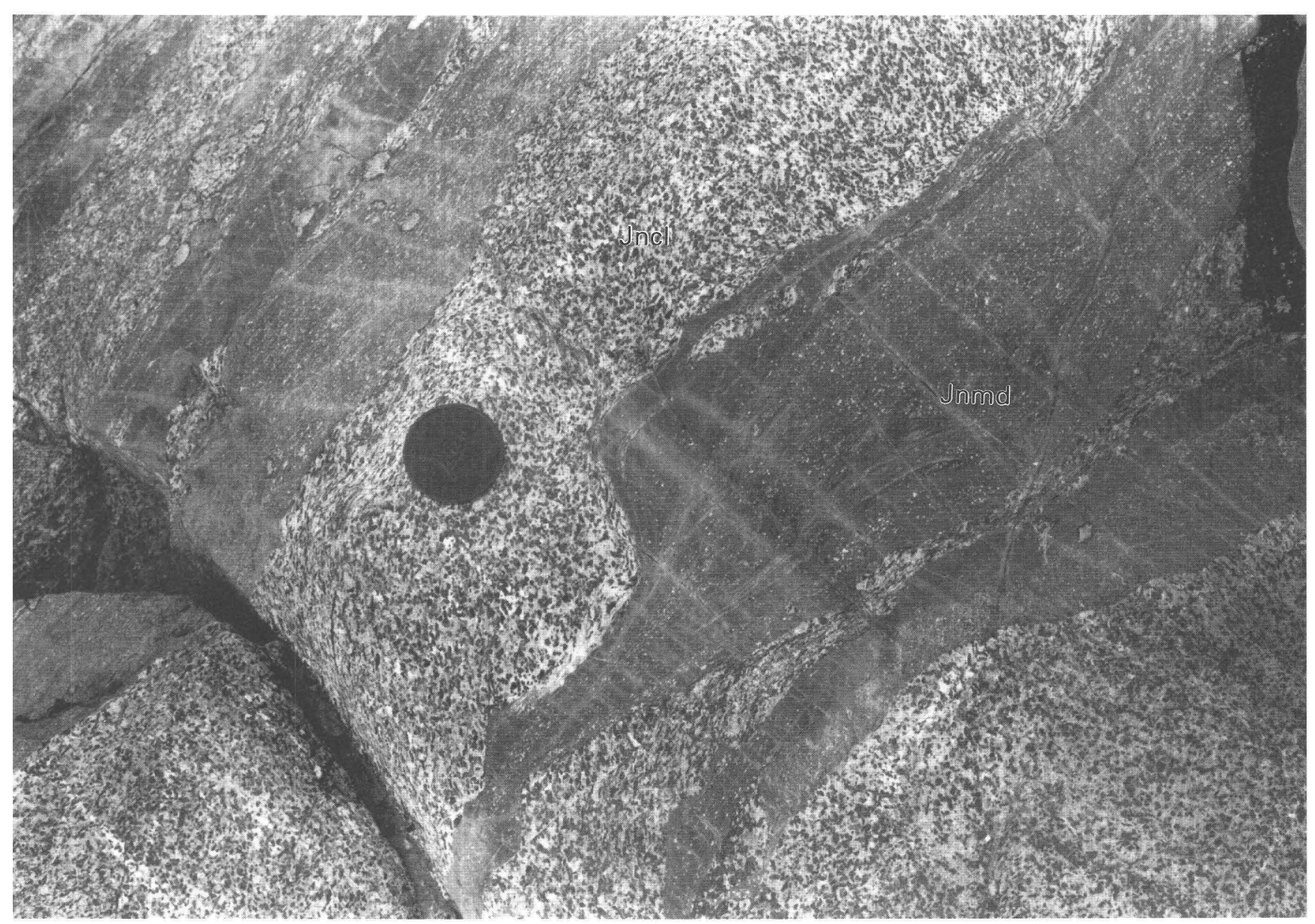

Figure 5. Fine-grained mafic dikes in cumulus-layered gabbronorite showing flow foliation and plastic deformation. Textures in cumuluslayered gabbronorite are similarly deformed, and pyroxenes are largely altered to tan hornblende. Lens cap is $7 \mathrm{~cm}$ in diameter. Photograph by G.H. Pessel. 
orite are exposed over an area that extends 1,500 to possibly $2,100 \mathrm{~m}$ in length and $600 \mathrm{~m}$ in width; the width is limited by the narrow exposure (fig. 6). This complex consists entirely of dikes (including sills, as used in this report) with few or no intervening screens of previously crystallized cumulus gabbronorite. All inclusions and internal banding are subparallel to the walls of the intrusions. Most of the dike rocks have equigranular textures, but a few of the gabbronorites have porphyritic plagioclase.

The oldest dikes are composed of fine-grained gabbronorite; successively younger intrusions consist of increasingly coarse-grained gabbronorite, quartz diorite, and tonalite, except for a few fine-grained mafic dikes that intruded late in the formation of the dike complex. In terms of mineralogy and characteristic field relations, each type of gabbroic dike rock is gradational to the gabbroic dike rock intruded next in the sequence. The dike rocks are discussed later in the order of their intrusion-based on crosscutting relationships-from oldest to youngest.

\section{FINE-GRAINED GABBRONORITE AND HORNBLENDE GABBRONORITE (Jnfg)}

Fine-grained (0.1-0.25 mm) gabbronorite and hornblende gabbronorite constitute the oldest recognizable unit in the dike complex; the age relations are based on the apparent absence of host rock for this intrusive unit and the presence of the fine-grained rock as a common inclusion in many of the other intrusions. These rocks typically are dark green from chloritic alteration. Textures are obscure in hand specimen because of weathering, fine grain size, and chloritization. Gradational contacts between the fine-grained gabbronorite (Jnfg) and the podiform hornblende gabbronorite (Jnpg) suggest that the fine-grained gabbronorite unit is a variation of the podiform hornblende gabbronorite unit (see section "Podiform Hornblende Gabbronorite"). The pods of coarse crystals characteristic of the otherwise fine-grained podiform hornblende gabbronorite are absent or very poorly developed in the fine-grained gabbronorite unit. The gradational contacts and the grain size of the fine-grained gabbronorite suggest that the unit formed in nearly the same manner as the podiform hornblende gabbronorite unit, that is, as multiple narrow dikes (see section "Features Suggesting Intrusion of Fine-Grained Gabbronorite as Dikes").

Petrographic study indicates that these rocks originally contained 15 to 25 percent orthopyroxene (hypersthene?), 15 to 25 percent augite, 40 to 60 percent plagioclase, 0 to 20 percent hornblende, and 4 to 8 percent primary postcumulus magnetite and ilmenite. Orthopyroxene, clinopyroxene, and plagioclase are typically subhedral, but

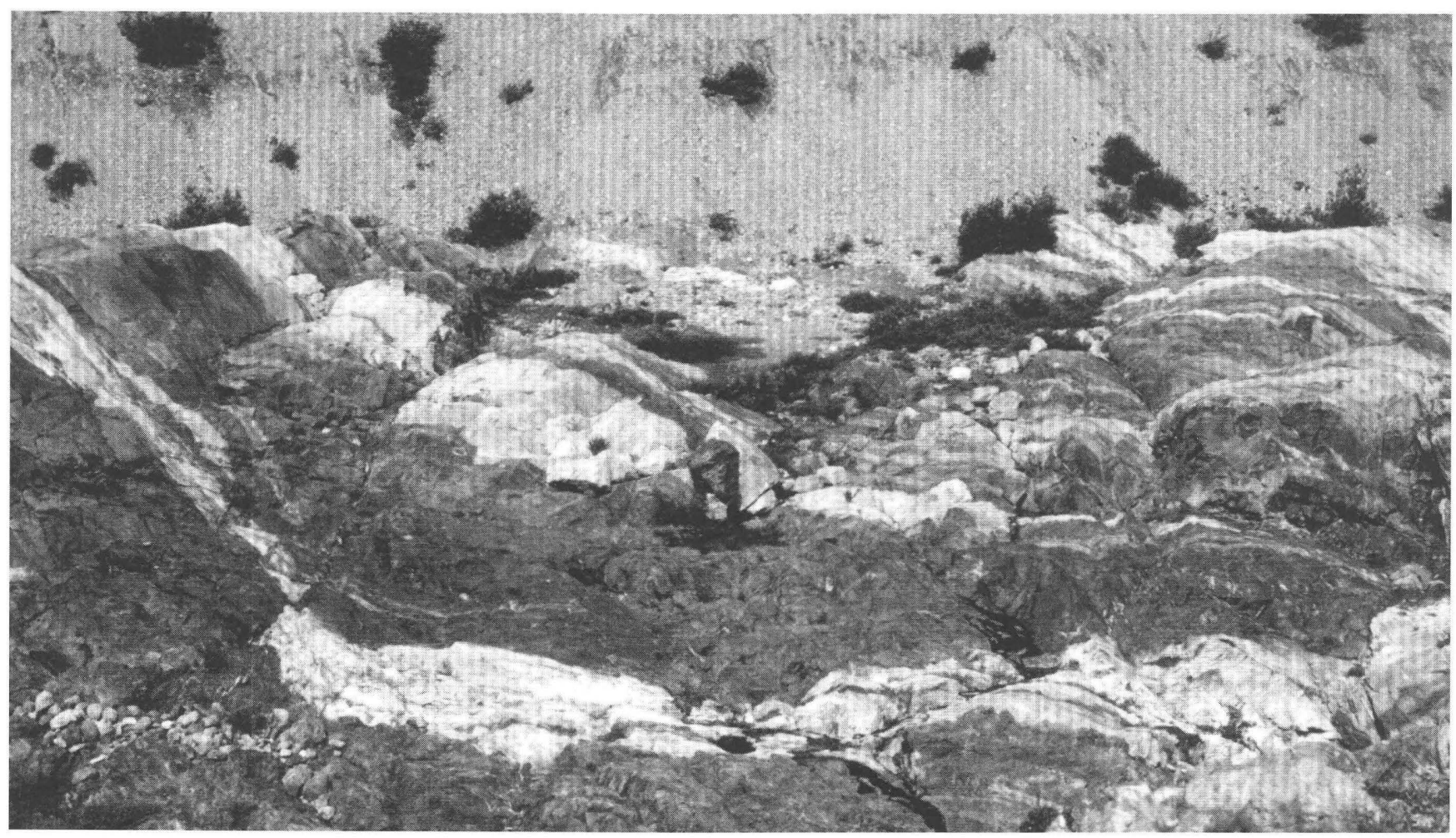

Figure 6. View of part of dike complex. Longest dimension of outcrop is about $100 \mathrm{~m}$. White layers are 3-to 5-m-wide dikes composed of leucocratic gabbronorite dikes or quartz diorite. Dark layers are composed of multiple fine-grained gabbronorite dikes (mostly podiform hornblende gabbronorite). View to north with moraine in background. 
some rocks contain both cumulus and postcumulus plagioclase. Hornblende in these rocks is a light greenish tan to light brown in thin section; typically, it forms small postcumulus crystals and, very rarely, rims on pyroxene crystals.

Two major deuteric-alteration assemblages are present in these rocks. The high-temperature alteration transformed most of the orthopyroxene to cummingtonite/ anthophyllite and about 75 percent of the plagioclase to clinozoisite. The later, low-temperature hydrothermal circulation resulted in formation of chlorite from the cummingtonite/anthophyllite, epidote from the clinozoisite, and chlorite-clinozoisite pseudomorphs after clinopyroxene. Although alteration is extensive, the primary igneous textures are usually well preserved.

\section{PODIFORM HORNBLENDE GABBRONORITE (Jnpg)}

Fine-grained (0.1-0.25 mm) hornblende gabbronorite and gabbronorite that are characterized by centimeter-scale banding and locally abundant lenticular pods of coarsegrained (as much as $1 \mathrm{~cm}$ ) crystals, dominantly hornblende, compose the podiform hornblende gabbronorite unit (fig. 7). This unit is gradational in texture from that of the finegrained gabbronorite (Jnfg) to that of the mixed gabbroic rocks unit (Jnmx); the podiform hornblende gabbronorite crops out between these two units, is present as inclusions in the mixed gabbroic rocks unit, and is interpreted as the second oldest unit in the dike sequence. Pod abundance in this unit varies from very low to high; in extreme cases, the pods form parallel, continuous bands (fig. 7). These rocks are typically greenish black due to chloritization. Late quartz-epidote veining is locally common.

The subparallel pods and bands are typically spaced 2 to $3 \mathrm{~cm}$ apart. Boundaries between the coarse-grained pods and the surrounding finer grained rock are gradational. The fine-grained gabbronorite between the pods is identical to the fine-grained gabbronorite unit (Jnfg; see section "FineGrained Gabbronorite and Hornblende Gabbronorite") and probably formed as multiple narrow dikes (see section "Features Suggesting Intrusion of Fine-Grained Gabbronorite as Dikes"). The coarse-grained pods and bands in the podiform hornblende rock typically consist of 70 to 90 percent coarsegrained magnesiohornblende, 10 to 20 percent plagioclase, and 10 to 20 percent magnetite and ilmenite. Hornblende is pale greenish tan in thin section and typically occurs as coarse, prismatic, subhedral crystals, although interstitial and (or) poikilitic hornblende are also common. In the coarsegrained pods, magnetite and ilmenite crystals are larger (0.2$0.4 \mathrm{~mm})$ than in the fine-grained rocks $(0.05-0.1 \mathrm{~mm})$ and locally occur as subhedral crystals. Plagioclase is also commonly more coarse grained in the pods than in the finegrained rock.
Hornblende is probably a late-magmatic phase that crystallized over a long period of time as it forms very coarse, subhedral to anhedral crystals. In a very few rocks, hornblende is pseudomorphous after pyroxene (presumably clinopyroxene). The general absence of hornblende growing on or within clinopyroxene crystals implies that the clinopyroxene was still a stable phase when the hornblende formed. Also, the plagioclase, clinopyroxene, and orthopyroxene enclosed within poikilitic hornblende have generally retained their original, commonly euhedral, crystal shapes; thus it appears that the hornblende did not form from these minerals. Most of the inclusions in the hornblende are completely pseudomorphous low-temperature minerals, such as the late-formed chlorite pseudomorphs after orthopyroxene.

The lenticular pods and bands of coarse crystals in the podiform hornblende gabbronorite unit must have formed from a water-rich magma or aqueous solution. A water content of 3 weight percent in magma is needed for hornblende to crystallize independently of pyroxenes (Gill, 1981, p. 196). Whether the water was present in the initial magma or was introduced along the dike walls when the unit was still fairly hot is not known with certainty. However, the hornblende gabbronorite's texture, mineralogy, and rock-compositional data suggest that water was introduced during a catastrophic event. A plot of $\mathrm{FeO}^{*} / \mathrm{MgO}$ versus $\mathrm{SiO}_{2}$ (fig. 8) shows that the $\mathrm{FeO}^{*}$ content of the rock varies inversely with the $\mathrm{SiO}_{2}$ content, rather than the normal direct relationship characteristic of differentiated igneous rocks. Additionally, the major-oxide composition of the podiform hornblende gabbronorite (table 1) does not resemble the composition of a primary magma or a mixture of primary magmas.

The major-oxide composition of the podiform hornblende gabbronorite was probably produced by hightemperature alteration of the primary rock by a metasomatic fluid; such a fluid phase moving along the dike walls would encourage growth of coarse crystals and abundant crystallization of opaque minerals. Three possible sources for the fluid include (1) later intrusions, (2) deeply circulating, evolved marine waters, and (3) metamorphic inclusions. Some of the later gabbronorite dikes (intruding the podiform hornblende gabbronorite) contain inclusions of the podiform hornblende gabbronorite but do not themselves contain abundant hornblende except in minor pegmatitic pods. Therefore fluid probably was introduced into the podiform hornblende gabbronorite unit prior to most of the intrusions of the later gabbronorite dikes. Field relations imply that the intrusions of quartz diorite occurred after the gabbronorite dikes were emplaced, and so they too are not likely to have contributed fluid. Thus an evolved marine hydrothermal system or assimilated metamorphic rocks containing hydrous phases are more likely than later intrusions to be the source for the fluid. 


\section{MIXED GABBROIC ROCKS (Jnmx)}

The mixed gabbroic rocks unit is composed of medium-grained gabbronorite and hornblende gabbronorite that formed during one or more intrusive events; this unit commonly contains abundant inclusions of fine-grained gabbronorite (fig. 9). The textures in the unit are identical to schlieren textures of migmatites (Mehnert, 1968). However, field relationships suggest that the migmatitic-appearing textures formed by multiple intrusion and flow and not by partial melting of preexisting rock as the term often implies (Mehnert, 1968). The textures of the mixed gabbroic rocks unit are gradational with those in the podiform hornblende gabbronorite (Jnpg) and in the inclusion-rich gabbronorite dikes (unit Jnigi).

The mixed gabbroic rocks unit is characterized by a wide variation in grain size (fig. 9). Lenses (1-2 cm wide) of coarse hornblende, plagioclase, magnetite, and ilmenite-resembling those in the podiform hornblende unit (Jnpg) — and abundant lenticular inclusions of fine-grained gabbronorite and hornblende gabbronorite (Jnfg) are sur- rounded by medium-grained gabbronorite and hornblende gabbronorite. Flow(?) foliation is common. Although most of the unit apparently resulted from a single intrusion, the medium-grained gabbronorite appears to have been emplaced locally as several intrusions. Diffuse and gradational dike walls may obscure distinctions between individual intrusions of medium-grained gabbronorite elsewhere in the unit. The unit is typically light gray with darkgray inclusions, but green chloritized rocks are also present.

\section{BANDED GABBRONORITE (Jnbg)}

The gabbronorite with banded structure is composed of dark-weathering, fine-grained gabbronorite intruded by coarser grained, lighter-weathering gabbronorite dikes (fig. 10). The two types of gabbronorite typically form parallel bands, 2 to $3 \mathrm{~cm}$ thick, and have sharp contacts. The coarser grained dikes have extremely narrow, chilled borders and clearly crosscut the finer grained rock.

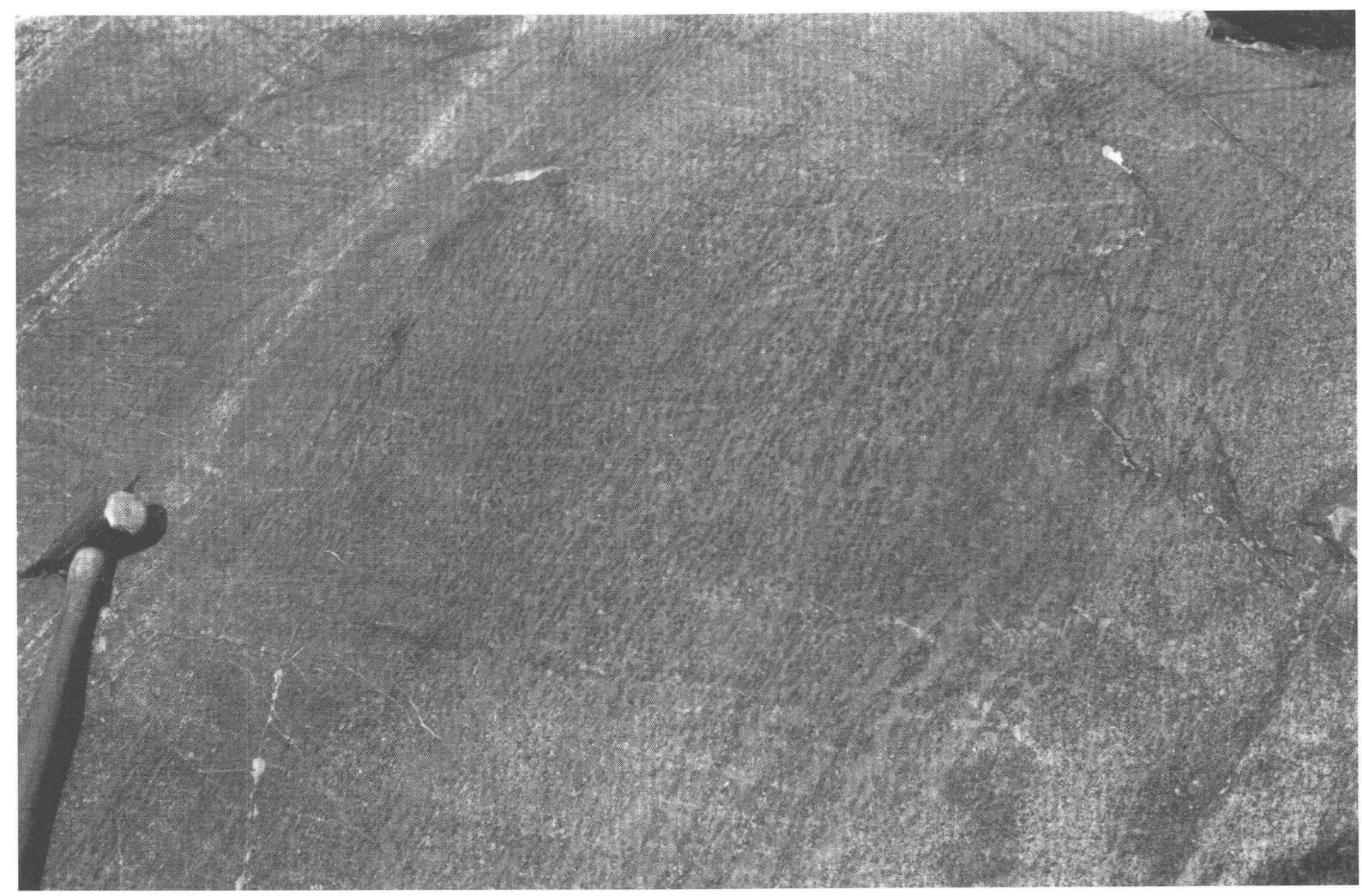

Figure 7. Podiform hornblende gabbronorite. A, Subparallel lenticular pods of coarse hornblende, magnetite, ilmenite, and plagioclase. Hammer for scale. Photograph by G.H. Pessel. $B$, Subparallel bands of coarse hornblende, magnetite, ilmenite, and plagioclase superimposed on lighter colored hornblende gabbronorite. Hammer for scale. 
The banded gabbronorite unit is similar to the mixed gabbroic rocks unit ( $\mathrm{Jnmx}$ ) in that both units contain finegrained gabbronorite intruded by medium-grained gabbronorite. However, the mixed gabbroic rocks unit shows a range of grain sizes and probably has many diffuse contacts, whereas the banded gabbronorite unit contains only two grain sizes and has no gradational contacts.

\section{MEDIUM-GRAINED ISOTROPIC GABBRONORITE DIKES (Jnigi, Jnigd)}

Medium-grained gabbronorite dikes, 3- to 5-m wide (fig. 6), crosscut and intrude the podiform hornblende gabbronorite unit (Jnpg). Most of the whiteweathering dikes are composed of plagioclase (70-85 percent), pyroxenes (10-30 percent), hornblende (0-10 percent), and opaque minerals ( $0-4$ percent) and are probably small bodies of the isotropic gabbronorite unit (Jnig). Some of the dikes may be dioritic in composition. These gabbronorite dikes typically have sharp contacts and fingerlike apophyses into the surrounding podiform hornblende gabbronorite (fig. 11). The locally gradational contact on the north side suggests diffusion of aqueous solutions across this boundary.

Dikes contain varying amounts of inclusions, and some dikes have none. The grain size and possibly the abundance of the plagioclase increase as the number of inclusions decreases. Inclusions in these dikes commonly are sheets, $30 \mathrm{~cm}$ wide, that consist of the podiform hornblende gabbronorite unit (Jnpg; fig. 12). Dikes with few or no inclusions typically have pegmatitic cores composed of coarse hornblende and plagioclase.

Secondary minerals include cummingtonite anthophyllite, clinozoisite, epidote, chlorite, sphene, and pyrite.

\section{QUARTZ DIORITE AND TONALITE (Jnqd)}

Quartz diorite and tonalite intruded the dike complex as narrow (less than $4 \mathrm{~m}$ thick) dikes (fig. 6), typi-

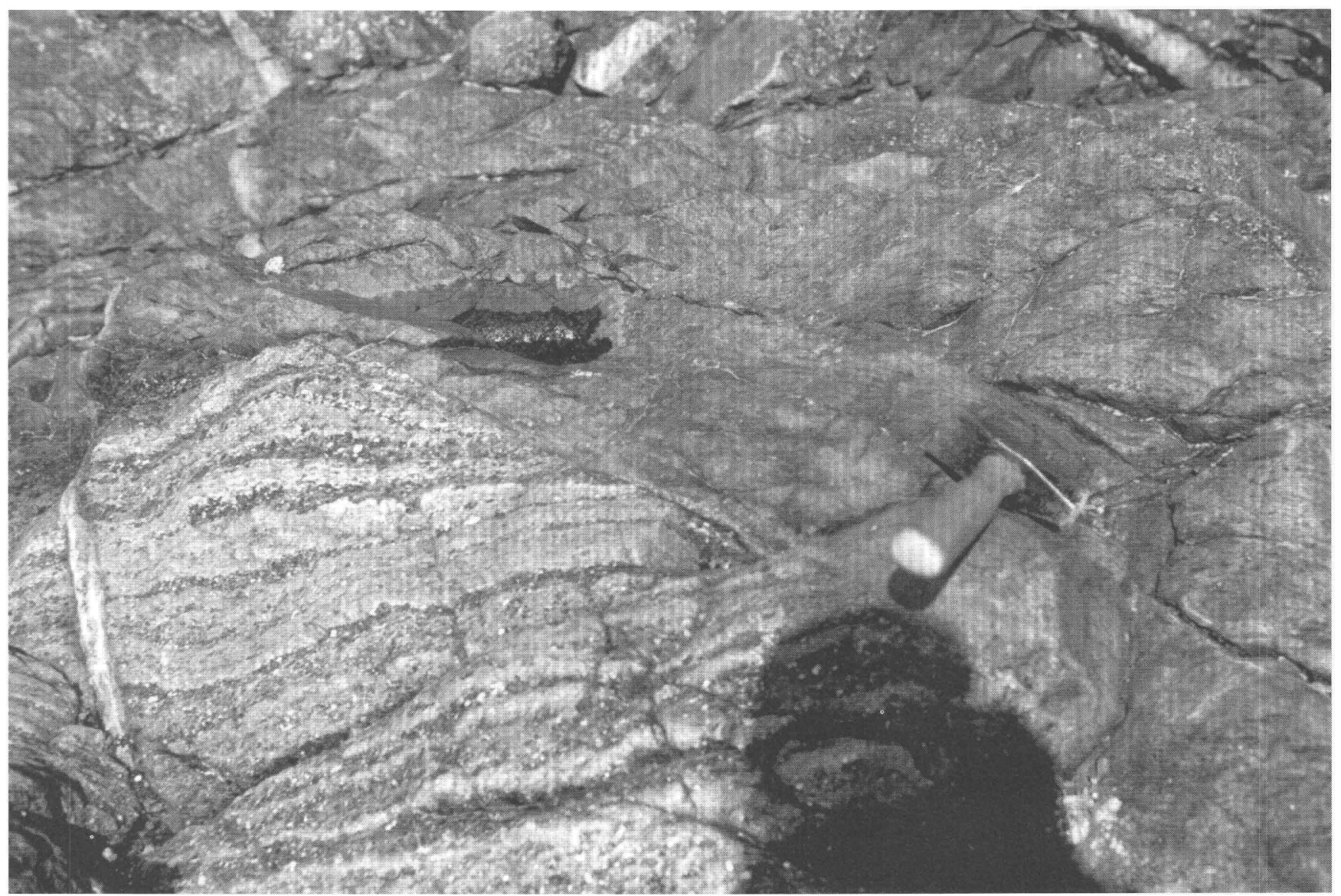

Figure 7. Continued. 


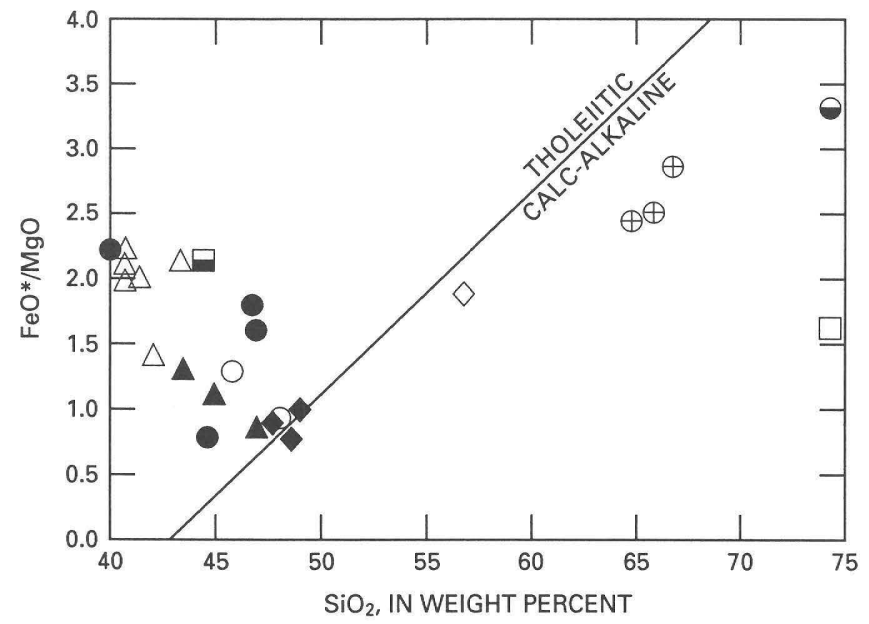

EXPLANATION

GABBRONORITE AND RELATED ROCKS

- Cumulus-layered gabbronorite (Jncl)

$\triangle \quad$ Fine-grained gabbronorite (Jnfg) and podiform hornblende gabbronorite (Jnpg)

घ Banded gabbronorite (Jnbg)

Mixed gabbroic rocks (Jnmx)

- Gabbronorite dikes and massive gabbronorite (Jnigi, Jnigd, Jnig)

- Mafic dikes (Jnmd)

$\diamond \quad$ Mixed gabbroic rocks and quartz diorite, undivided (Jngq)

QUARTZ-RICH PLUTONIC ROCKS

$\oplus \quad$ Quartz diorite (Jnqd)

- Altered quartz diorite (Jnqd)

Trondhjemite (Kt)

Figure 8. Variation of $\mathrm{SiO}_{2}$ with $\mathrm{FeO} * / \mathrm{MgO}$ (bulk-compositional data) for rocks of the Nelchina River Gabbronorite. Analyses were corrected for loss on ignition and $\mathrm{H}_{2} \mathrm{O}^{-}$and were normalized to 100 percent. $\mathrm{FeO}^{*}$, total iron as $\mathrm{FeO}$. Line for distinguishing between tholeiitic and calc-alkaline trends from Miyashiro (1974).

cally subparallel to the foliation in the gabbroic rocks. One small quartz diorite and tonalite body, with apophyses parallel to the foliation in the gabbroic rocks, is present in the southern part of the dike complex. The quartz content is variable, and no attempt was made in the field to distinguish between tonalite and quartz diorite. These rocks will hereafter be referred to as quartz diorite.

The quartz diorite is medium grained, light gray, and bleached white where altered. A greenish tint (due to chloritization) and spotty limonite staining accompanies the bleaching. Unaltered quartz diorite is composed of plagioclase (40-65 percent), quartz (15-30 percent), and hornblende (10-25 percent), with minor amounts of opaque phases. K-feldspar is not present. Most quartz grains are blue in hand specimen and are typically interstitial. Inclusions of small rods of apatite are common. Plagioclase, typically subhedral, appears to be slightly zoned, but strain produced by deformation makes this difficult to determine. Green hornblende forms medium-grained (1-4 mm), subhedral crystals.

Alteration of the quartz diorite is extensive. Plagioclase is altered to clinozoisite, albite, and commonly small amounts of fine-grained epidote and white mica. The plagioclase alteration assemblage in the quartz diorite is thus commonly distinct from the alteration assemblage in the gabbroic rocks, which does not include white mica. In more intensely altered quartz diorites, hornblende is partly or completely replaced by chlorite. Actinolite, a common low-temperature alteration product of hornblende, is not present.

A quartz-albite rock with less than 10 percent mafic minerals (dominantly hornblende altered to chlorite) is commonly present near the center of quartz diorite dikes and is in gradational contact with the quartz diorite. Locally the dike centers are pure quartz. The quartz-albite

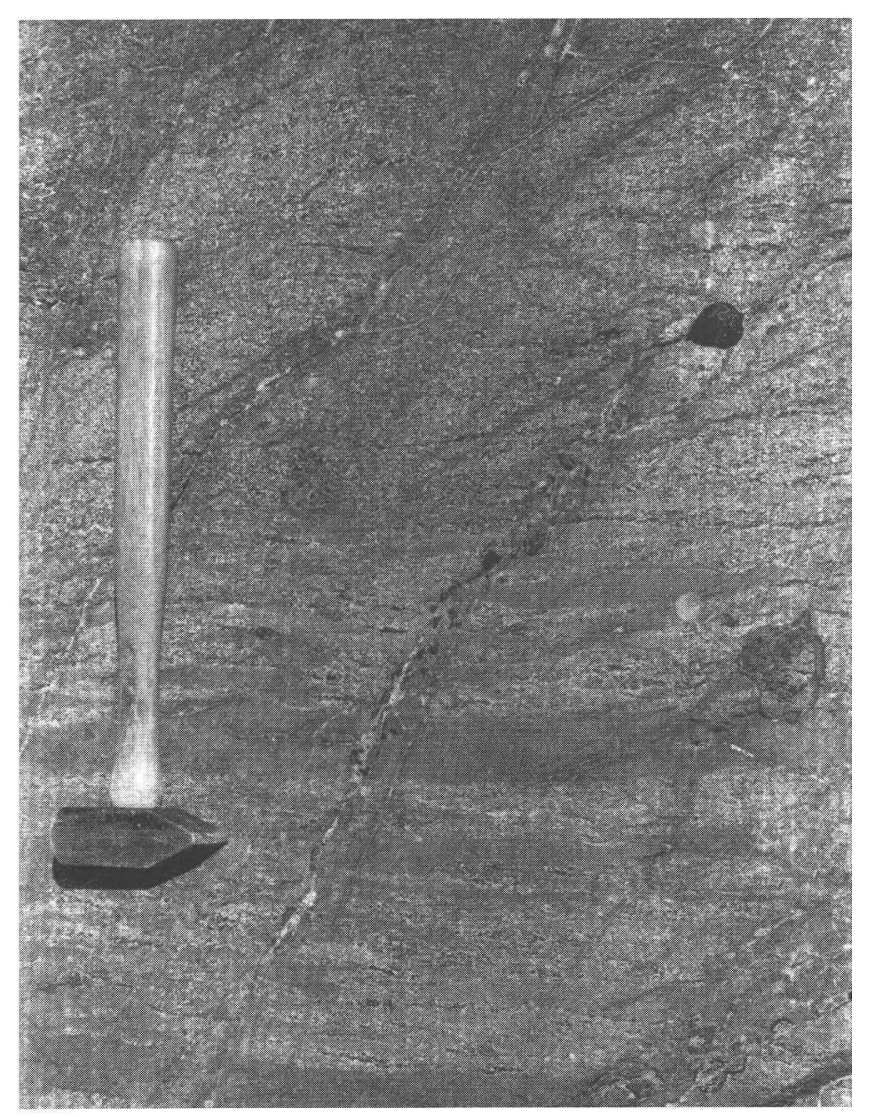

Figure 9. Mixed gabbroic rocks unit (Jnmx) showing lenticular inclusions of dark-gray, fine-grained gabbronorite and small coarsegrained pods (lenses) in light-gray-weathering, coarser grained gabbronorite. Note similarity to podiform hornblende gabbronorite (Jnpg). Photograph by G.H. Pessel. 
rock could be a leucocratic phase of the quartz diorite; however, it always bears chlorite and minor amounts of pyrite and is limonite stained. These observations suggest that this quartz-albite rock is an alteration product of the quartz diorite. The mineralogy and chemical composition of the quartz-albite rock closely resemble those of the trondhjemite dikes. The possibility that some of these leucocratic quartz diorites are trondhjemites that have intruded the quartz diorite and (or) gabbroic rocks cannot be entirely dismissed. This problem is discussed more fully in the section "Gabbronorite, Metasedimentary and Metavolcanic Rocks, Trondhjemite, and Felsite."

Contacts between the quartz diorite and the gabbronorite in the dike complex are sharp to gradational. A small amount of interstitial quartz is commonly present in the gabbroic rocks adjacent to the quartz diorite dikes in the dike complex. Quartz is not generally present in the gabbroic rocks of the Nelchina River Gabbronorite. The interstitial quartz may have formed in the gabbroic rocks by diffusion of silica if the gabbronorites were sufficiently hot when they were intruded by the quartz diorites. Early intrusion of the quartz diorites into the gabbroic rocks is suggested by textures seen in outcrop, such as foliation in the gabbroic rocks that is bent by dikes of quartz diorite (locations T1 and T3 in fig. 3). These textures suggest plastic movement of the gabbroic rocks during intrusion of the quartz diorite. Possible textural and structural evidence of the early intrusion of the quartz diorite is also provided by the fine-grained mafic dikes (see section "Mafic Dikes").

The small quartz diorite body in the southern part of the dike section (location T2 in fig. 3 ) contains abundant ovoid xenoliths of gabbronorite that also appear to have been plastically deformed (fig. 13). The xenoliths are composed of fine- and medium-grained gabbronorite and are oriented approximately northeast-southwest, probably parallel to a direction of flow. However, imbrication of the xenoliths has not been observed. In thin apophyses of the quartz diorite body, such xenoliths have apparently been so stretched as to be almost indistinguishable as xenoliths. The medium-grained gabbronorite xenoliths are more mafic than any other gabbronorites in the exposure,

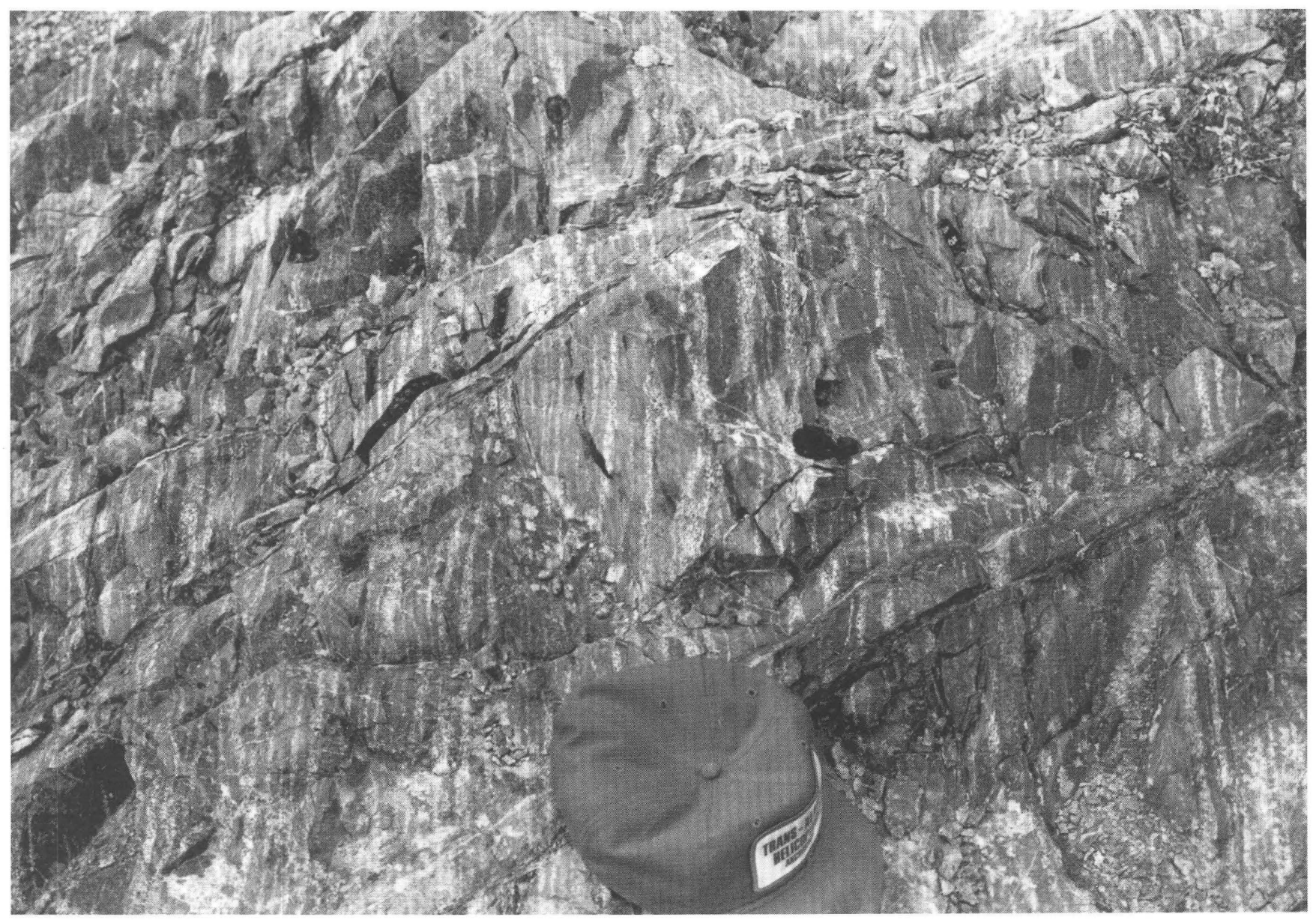

Figure 10. Banded gabbronorite, composed of dark-gray fine-grained gabbronorite intruded by 2- to 3-cm-wide dikes (or sills) of coarser grained, white (gray-weathering) gabbronorite. Hat for scale. Photograph by G.H. Pessel. 
with the exception of similar xenoliths in the gabbroic rocks just north of this quartz diorite body. The quartz dioritic and gabbroic magmas may have transported these anomalous gabbronorite xenoliths some distance from their original position.

\section{MAFIC DIKES (Jnmd)}

Fine-grained mafic dikes are commion along the Nelchina transect and consist dominantly of fine-grained (0.1-0.25 mm) hornblende gabbro and hornblende

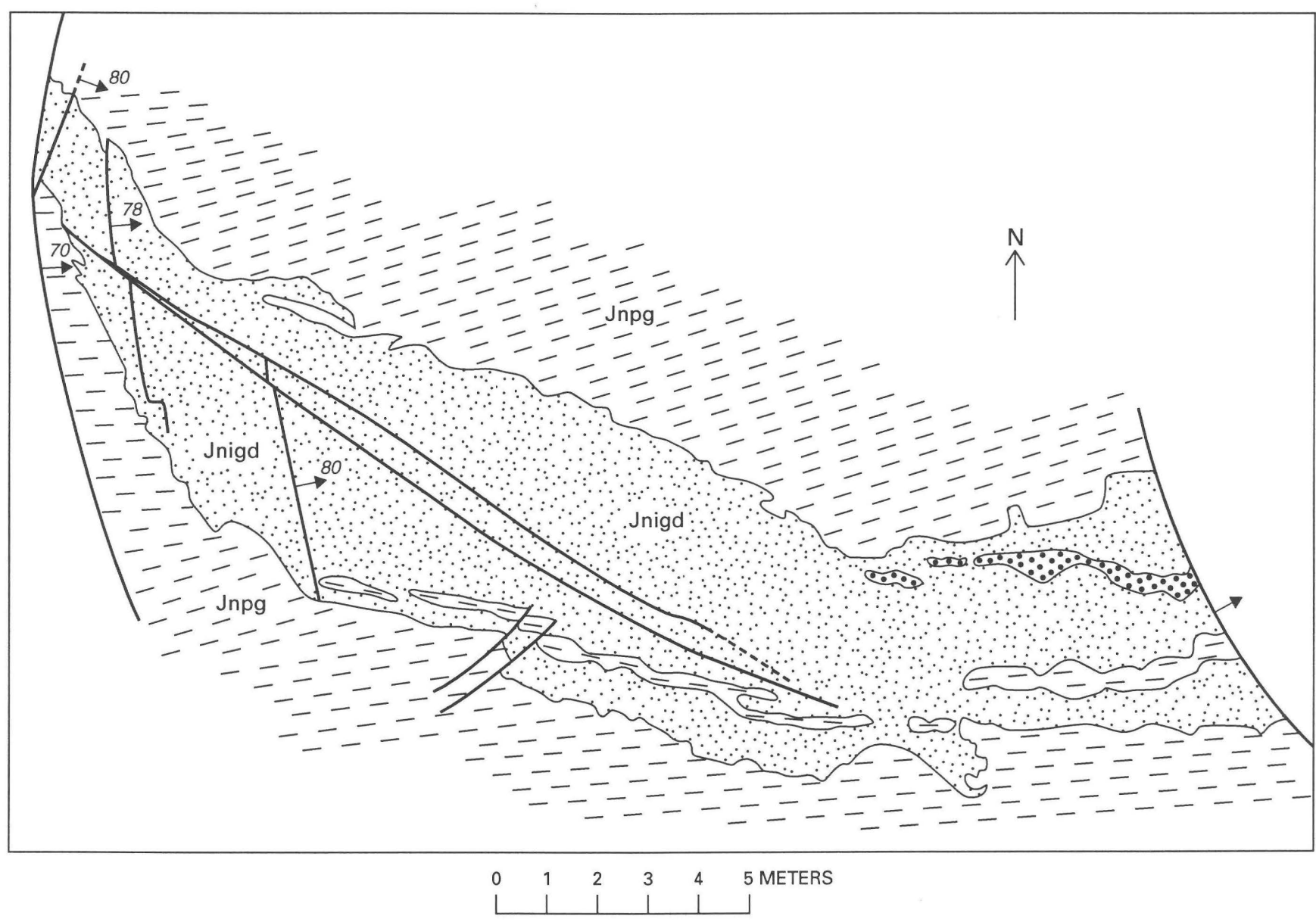

EXPLANATION

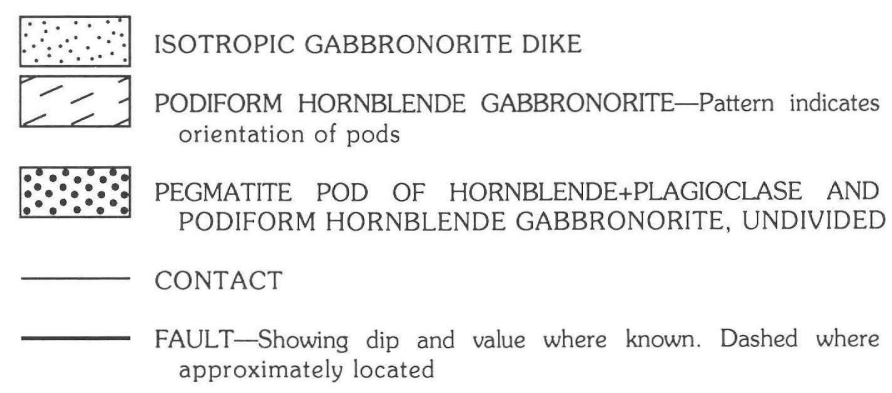

Figure 11. Detailed map of part of dike complex, showing isotropic gabbronorite dike that intruded the podiform hornblende gab-bronorite unit. Gabbronorite dike contains an elongate inclusion of the podiform hornblende gabbronorite unit and a pegmatite pod composed of coarse hornblende and plagioclase. 
gabbronorite. Dikes composed of hornblendite, minor gabbronorite, or pyroxenite are present but not abundant. Characteristics of some hornblende gabbro dikes are discussed in the section "Mafic Dikes Crosscutting Cumulus-Layered Gabbronorite." The mafic dikes intrude gabbroic, quartz dioritic, and metasedimentary and metavolcanic rocks along the transect. The mafic dikes appear to be the most magnesium-rich rocks in the Nelchina transect, ranging from 9 to 12 weight percent $\mathrm{MgO}$ (table 1).

The fine-grained dikes display important textures and structures. Local folding of and boudinaged structure in the dikes imply ductile movement of the country rocks after emplacement of the dikes. Near location T2 (fig. 3), subparallel mafic dikes crosscut both gabbronorite and quartz diorite. However, the dikes are intruded by the same rocks (both gabbronorite and quartz diorite) that they appear to intrude (fig. 14). These dikes either were injected into the less mafic crystal mush, cooled, and brittlely broken while the country rock flowed around them, or, less likely, were intruded by the gabbronorite and the quartz diorite. The presence of both deformed and undeformed dikes in other areas suggests that the mafic dikes were intruded over a considerable period of time.

\section{FEATURES SUGGESTING INTRUSION OF FINE- GRAINED GABBRONORITE AS DIKES}

The large amount of fine-grained gabbronorite in the area is unusual for a large pluton. Most mafic intrusions and even basalt flows, although fine grained near their margins, become coarser grained toward their centers. The fine-grained rocks along the Nelchina transect, however, crop out discontinuously and occur as inclusions in later gabbronorite over an area at least 1,500 $\mathrm{m}$ long and show no coarsening of crystals near the center of this area. Quenching, perhaps due to rapid release of volatiles or rapid ascent of subvolcanic feeders and subsequent loss of pressure, may have caused the crystallization of large amounts of fine-grained rocks. However, field observations suggest that the thick sequence of fine-grained gabbronorite intruded as a series of thin dikes.

A widespread system of narrowly spaced linear fractures in the fine-grained gabbronorite is suggested some of the textural and structural features of the fine-grained gabbronorite: (1) parallel bands, $2 \mathrm{~cm}$ wide, intruded by coarser grained gabbronorite in the banded gabbronorite unit (Jnbg), (2) subparallel pods and continuous bands of

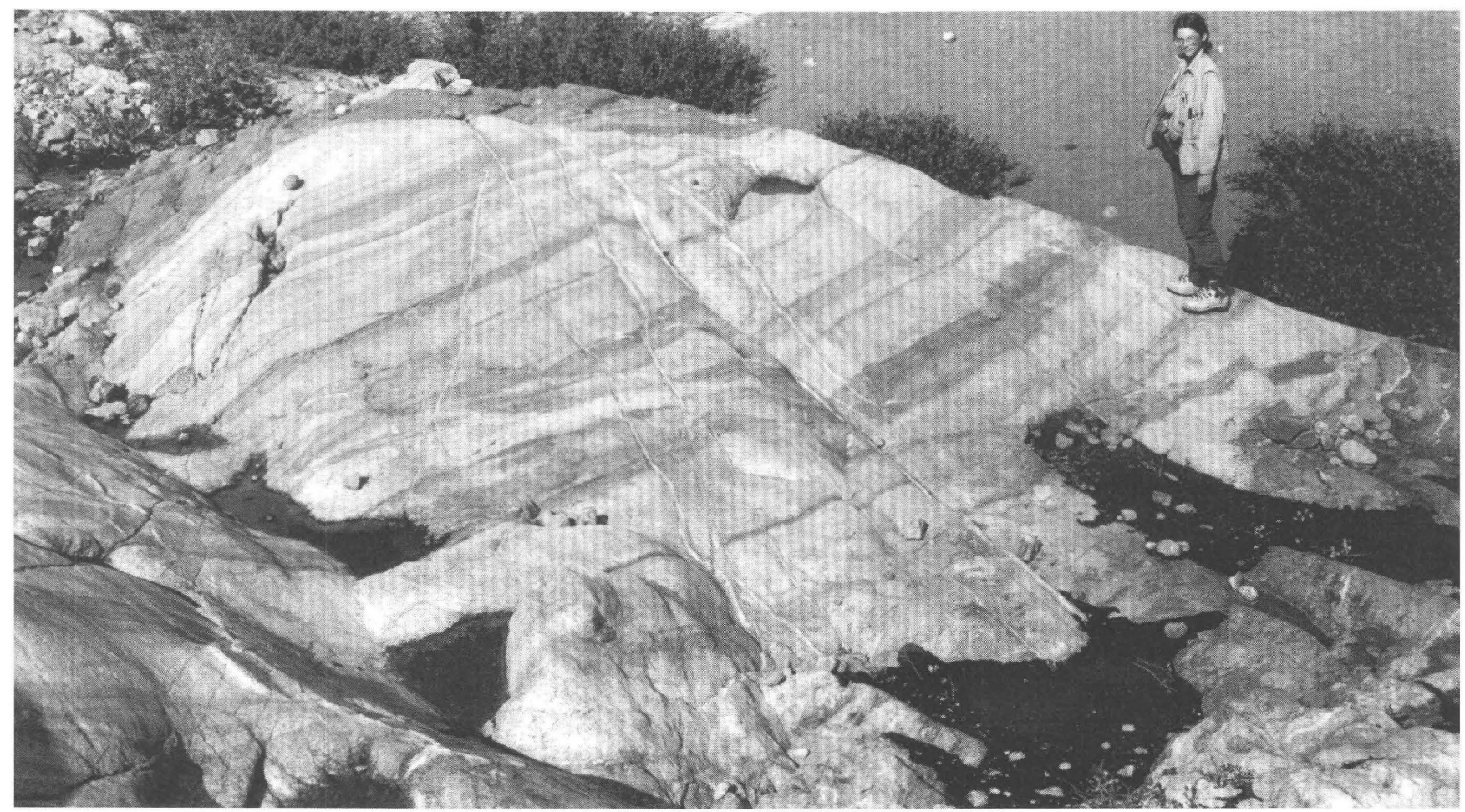

Figure 12. Light-colored gabbronorite dike (Jnigi) in central part of dike complex. Contains sheets of dark-weathering podiform hornblende gabbronorite (Jnpg). View to northeast. Photograph by G.H. Pessel. 
coarse crystals in the podiform hornblende unit (Jnpg), and (3) abundant elongate, narrow inclusions of the finegrained rock in the younger mixed gabbroic rock unit (Jnmx). These linear fractures in the fine-grained gabbronorite suggest that these rocks were emplaced as multiple narrow dikes.

Abundant aqueous solutions apparently produced the coarse pods in the podiform hornblende gabbronorite (Jnpg). After the formation of podiform hornblende gabbronorite, new magmatic intrusions formed the mixed gabbroic rocks (Jnmx), the banded gabbronorite (Jnbg), and the gabbronorite dikes (Jnigi and Jnigd). The transition from aqueous-vapor-dominated processes to dominantly magmatic activity may have occurred in a gradational manner. Whether a contact is sharp or diffuse is probably related to differences in the amount of magma as against fluid and the temperature differences between the intruding magma and the existing rock.

\section{ISOTROPIC GABBRONORITE INTRUDED BY QUARTZ DIORITE}

The third major lithologic group in the transect is composed of isotropic gabbronorite that is intruded by small plutons and dikes of quartz diorite (fig. 3). A few mafic dikes (Jnmd; see section "Mafic Dikes") are also present in this area.

\section{GABBRONORITE (Jnig)}

The isotropic gabbronorite in this area (fig. 3 ) is typically medium grained $(2-5 \mathrm{~mm})$ and massive, with almost no layering or flow foliation. White mats of clinozoisite (formed from plagioclase) stand out against the softer weathering, greenish-black alteration products of pyroxenes, giving these rocks a coarse salt-and-pepper ap-

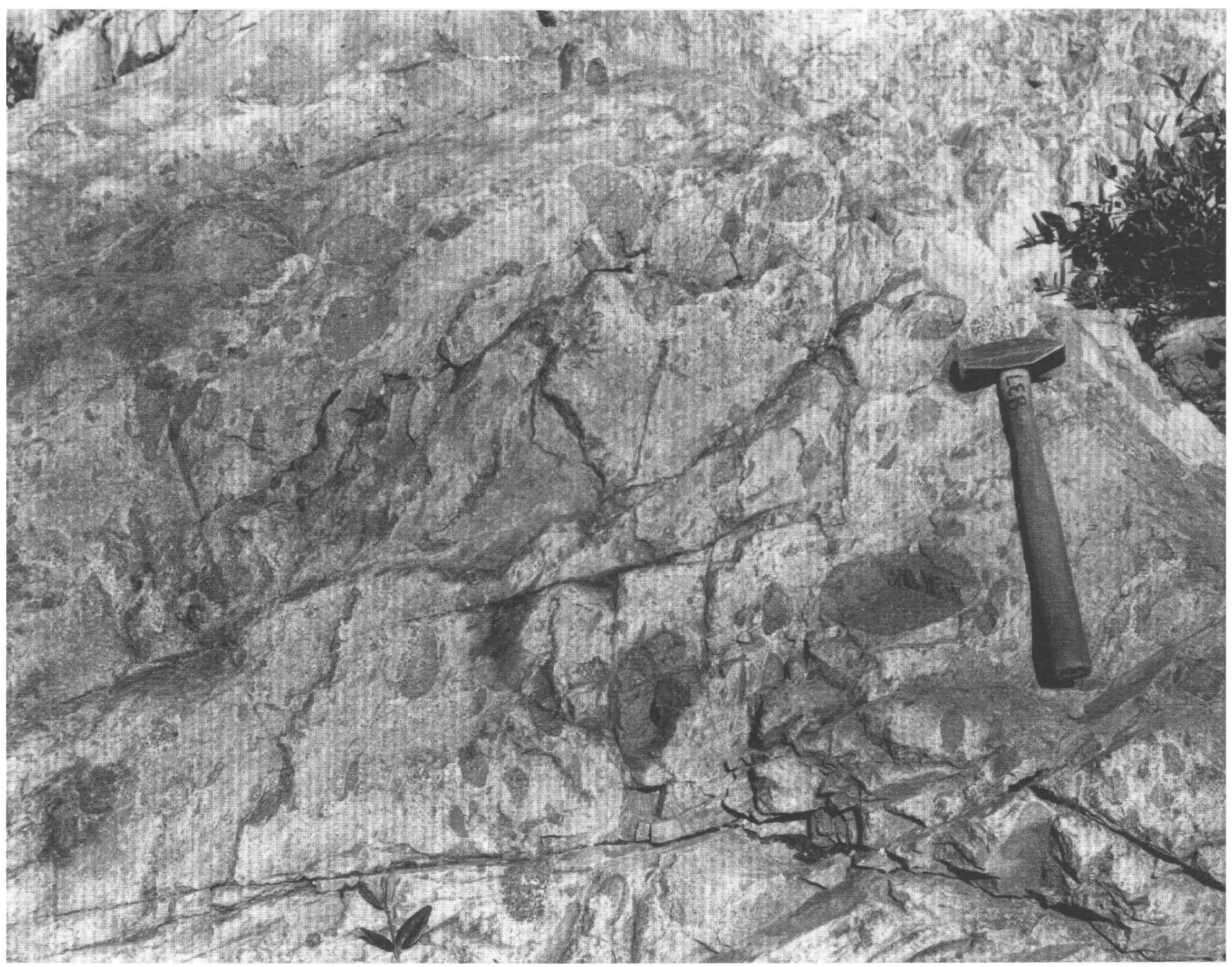

Figure 13. Quartz diorite body (Jngq) containing abundant ovoid and stretched xenoliths of gabbronorite.View to south. Photograph by G.H. Pessel. 
pearance. In addition to the common alteration productssuch as clinozoisite, cummingtonite/anthophyllite, chlorite, epidote, and minor albite-fibrous actinolitic amphiboles are common in this unit and increase in abundance toward the south. These isotropic gabbronorite bodies are probably slightly younger than the isotropic gabbronorite dikes (units Jnigi and Jnigd).

\section{QUARTZ DIORITE (Jnqd)}

The quartz diorite intruding the isotropic gabbronorite is the same as the quartz diorite of the dike complex, but the quartz diorite within the isotropic gabbronorite has larger areas of the quartz-albite rocks associated with it (see section "Dike Complex-Layered Rocks Produced From Multiple Intrusions of Gabbroic and Quartz Dioritic Magmas"). The quartz-albite rocks in this part of the Nelchina transect are extensively deformed and intensely stained with spotty limonite. In some outcrops, this highly deformed rock has an almost gneissic texture, and, in thin section, cataclastic textures are common. Quartz typically forms a fine-grained matrix around broken, strained plagioclase crystals. Quartz crystals are also strained, and some are recrystallized. Hornblendes in the quartz diorite are mostly altered to chlorite.

In areas of extensive alteration, quartz-albite rock and associated quartz-sericite-chlorite veins are abundant but typical quartz diorites are absent. Major-oxide compositions indicate that the quartz-albite rock is trondhjemitic However, field and petrographic relationships (discussed earlier) indicate that these rocks are essentially altered quartz diorite instead of a leucocratic phase of the quartz diorite or a primary trondhjemite.

\section{MIXED GABBROIC AND QUARTZ DIORITIC ROCKS (Jngq)}

Zones of complexly mixed gabbroic rocks and quartz diorite are present near the edges of small quartz diorite bodies. The contacts are variable in character and

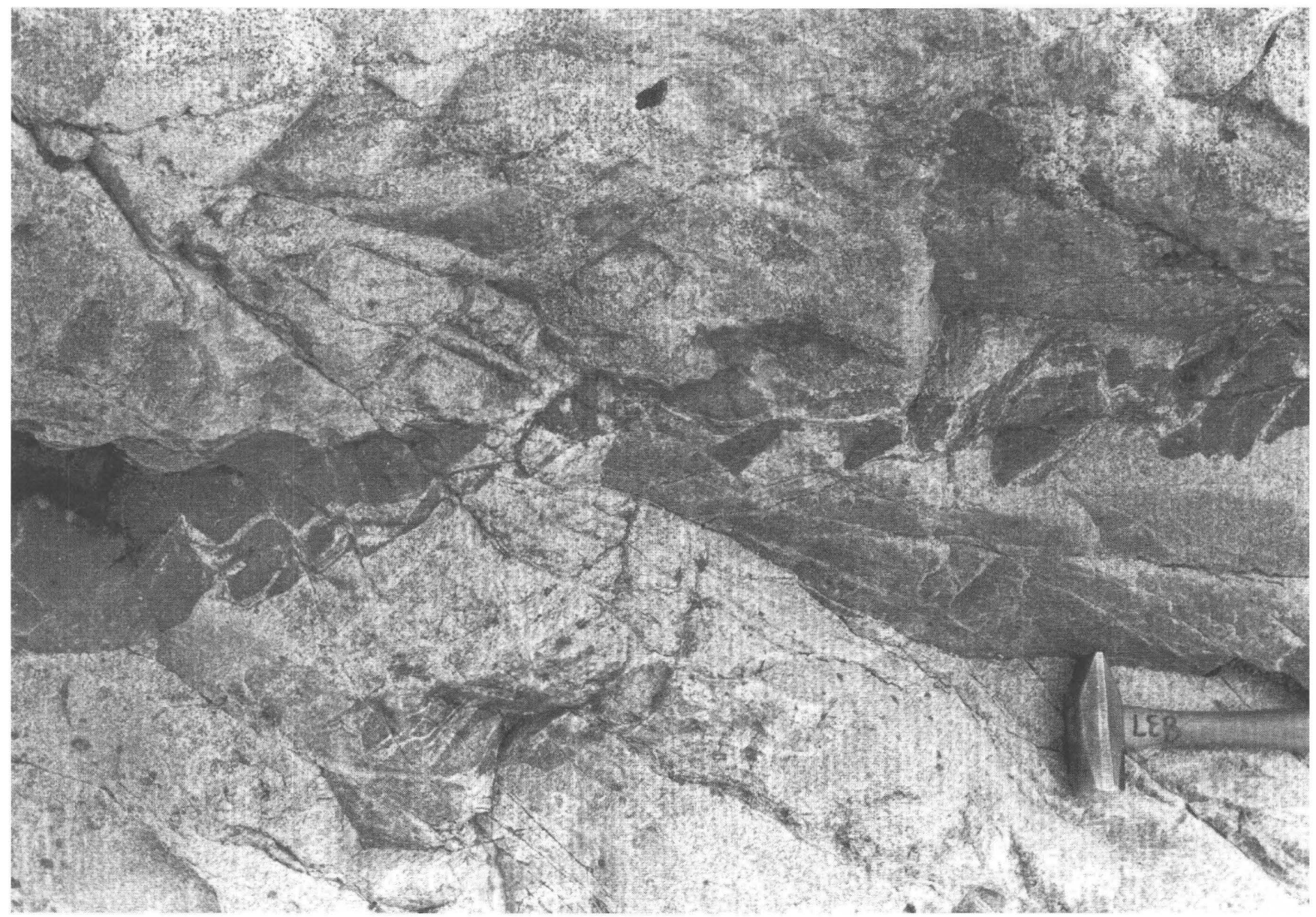

Figure 14. One of the fine-grained hornblende gabbro dikes that form discontinuous, subparallel trails in mixed gabbroic rocks unit (Jnmx) near location T2 of figure 3. (See section "Mafic Dikes" under "Dike Complex—Layered Rocks Produced from Multiple Intrusions of Gabbroic and Quartz Dioritic Magmas" in text.). Photograph by G.H. Pessel. 
include both sharp and gradational boundaries; migmatitictextured rocks in some boundary zones show the effects of plastic deformation. The most common texture consists of lenticular (stretched?) inclusions of gabbronorite in a matrix of quartz diorite, similar to schlieren textures of migmatites. Because the gabbroic inclusions commonly show plastic-deformation textures, apparently the gabbroic rocks were still hot when intruded by the quartz diorite. Some mixtures of gabbroic rocks, mafic dikes, and quartz diorite are folded (location T4 in fig. 3; fig. 15).

The mixtures of gabbroic and quartz dioritic rocks composing this unit (Jngq) texturally differ from the mixed gabbroic rocks unit ( $\mathrm{Jnm}$ ) in that the coarse pods of hornblende, magnetite, and plagioclase characteristic of the latter are not present in the mixtures of quartz diorite and gabbronorite. Additionally, the grain size is less variable in the mixtures of quartz diorite and gabbronorite than in the mixed gabbroic rocks unit.

\section{GABBRONORITE, METASEDIMENTARY AND METAVOLCANIC ROCKS, TRONDH- JEMITE, AND FELSITE}

Metasedimentary and metavolcanic rocks were intruded by gabbronorite and are present as large septa in the southern part of the map area. Gabbronorite forms both small dikes and sills in the metamorphic rocks and large sills of generally nonfoliated rock separating septa of metamorphic rocks. Locally the contact between the units is discordant (fig. 16). Narrow trondhjemite dikes, probably distinct from the quartz-albite rock discussed earlier, crosscut both the gabbroic and the metamorphic rocks. These dikes may be related to a late stage in the formation of the Jurassic arc. The metamorphic, gabbroic, and dike rocks were then intensely deformed and subsequently intruded by felsite dikes of probable Tertiary age (Winkler and others, 1981). Carbonate veins crosscut the felsite dikes.

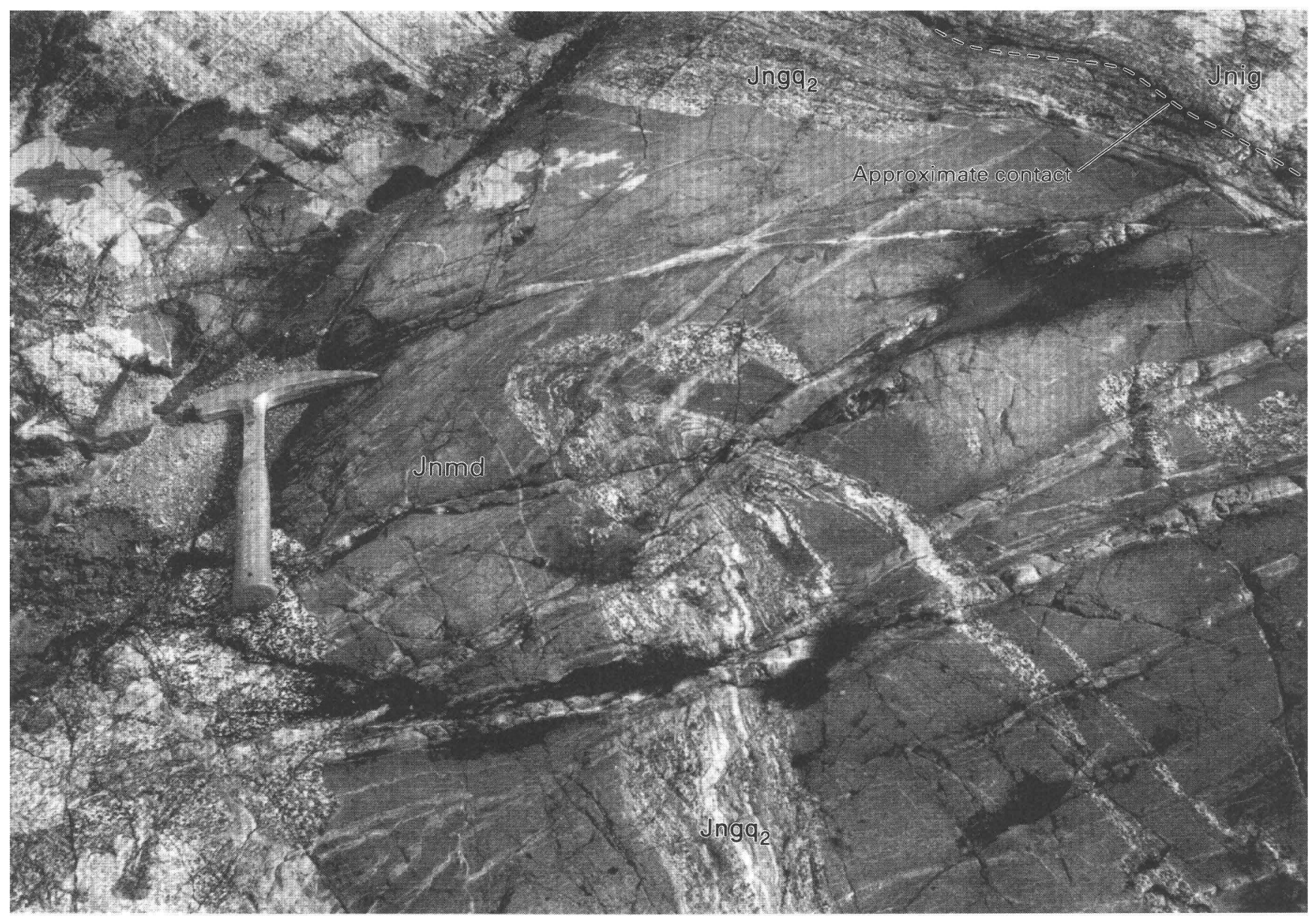

Figure 15. Mixture of quartz diorite and gabbronorite folded together with a large mafic dike; near contact between quartz diorite body and isotropic gabbronorite (location T4, fig. 3). Photograph by G.H. Pessel. 


\section{METASEDIMENTARY, METAVOLCANIC, AND GABBROIC ROCKS (Jnmg)}

The sedimentary and volcanic rocks are thermally metamorphosed to pyroxene hornfels grade by the gabbroic magma. This metamorphism and subsequent retrograde alteration have made determination of the protoliths uncertain. Petrographic study, however, suggests that mafic volcanic rocks (40 to 50 percent hornblende) and impure limestone are the most likely protoliths.

In this unit, septa of gneissic metamorphic rocks are separated by sills of gabbroic rocks. Contacts between the metamorphic and gabbroic rocks are diffuse and include extensive concordant migmatitic border zones. The orientation of the metamorphic fabric at the center of the septa is also concordant with the fabric of the gabbroic rocks. Thus, the mechanism of emplacement appears to involve syntectonic flow. The medium- to high-grade metamor- phism of the metamorphic rocks and the contact features just mentioned fit the criteria for catazonal intrusions (Buddington, 1959), suggesting that the depth of emplacement for the gabbroic rocks was 10 to $20 \mathrm{~km}$.

The metamorphic rocks are characterized by gneissic textures, grossularitic garnet layers, and a few thin beds of siliceous marble (probably representing recrystallized argillaceous limestones). The garnet-rich zones are generally less than $1 \mathrm{~m}$ wide and can be traced discontinuously for $200 \mathrm{~m}$ or more. Small areas of the metasedimentary and metavolcanic rocks with their characteristic metamorphic textures and minor occurrences of calc-silicate marbles are recognizable among the altered gabbronorites that contain abundant disseminated magnetite (alteration map unit dm; see pls. 1,2). The same metamorphic rocks may be present in the pervasively altered gabbroic rocks unit (Jnag) to the west, but the rocks are too sheared, deformed, and chloritized to distinguish in outcrop with certainty.

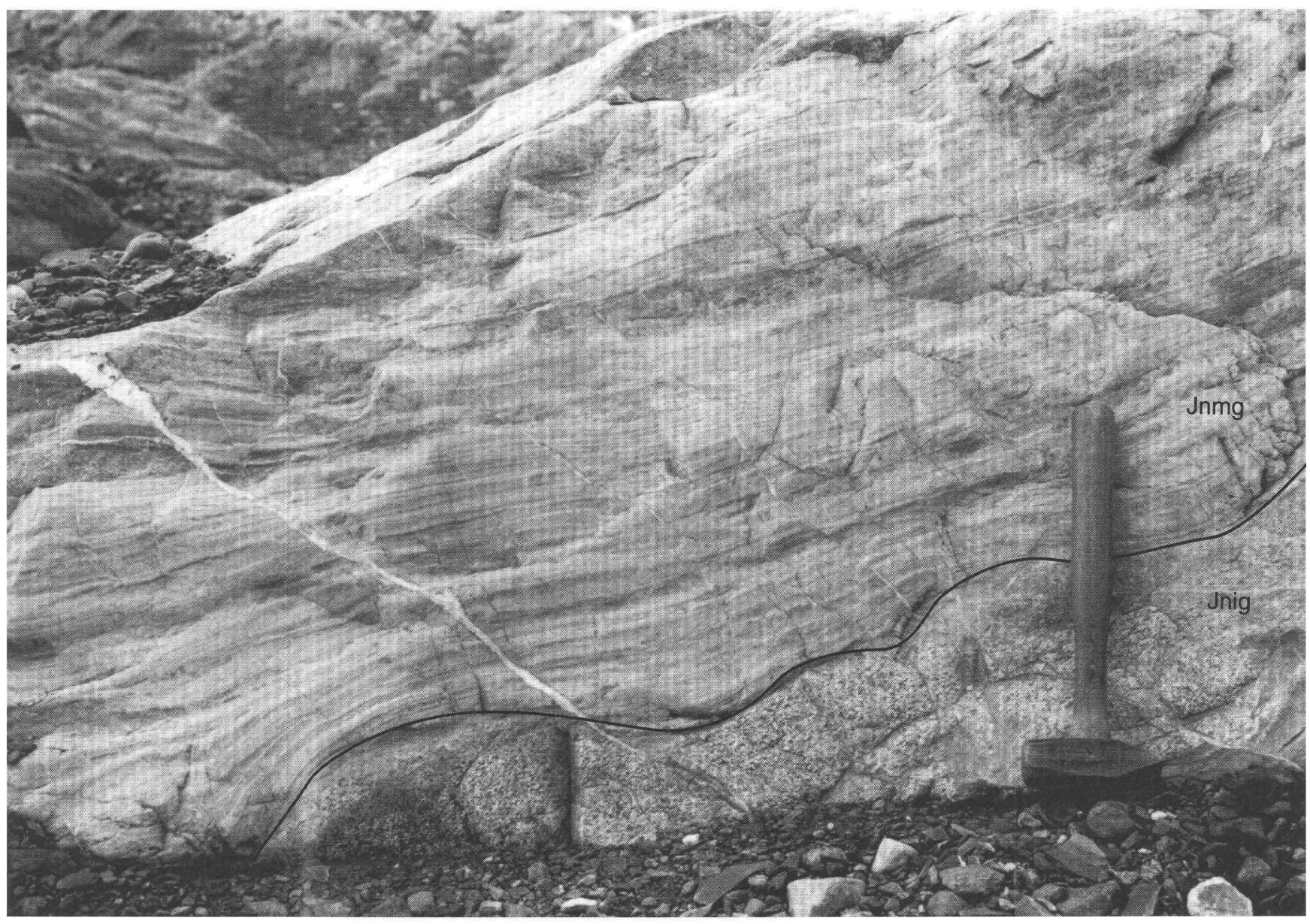

Figure 16. Thinly laminated mafic-volcanic and calcareous hornfels intruded by isotropic gabbronorite near south end of transect (shown near bottom of photograph). Photograph by G.H. Pessel. 
In the highest temperature assemblage, these metamorphic rocks consisted of thinly layered $(0.5-10 \mathrm{~cm})$ plagioclase-hornblende-quartz, plagioclase-clinopyroxene, and garnet-clinopyroxene-calcite \pm quartz rocks and garnetpyroxene skarn. Metasomatic skarn is indicated by (1) the presence of garnets with anisotropic rims, (2) evidence of garnet-clinopyroxene assemblages forming directly from clinopyroxene-plagioclase layers by prograde reaction, and (3) the presence of veins of garnet.

Subsequent lower temperature metamorphism has extensively altered the high-temperature assemblages. Clinopyroxene is replaced by quartz-calcite-chlorite \pm pyrite, and partial replacement of garnet and plagioclase by epidote, clinozoisite, chlorite, calcite, and minor pyrite is common.

Petrographic analysis of the metamorphic rocks has been cursory. The protoliths apparently were mafic volcanic rocks with minor amounts of impure limestone and possibly sandstones and shales. Without further data, determination of the provenance for this sequence of rocks is not possible.

\section{TRONDHJEMITE DIKES (Kt)}

White-weathering trondhjemite intrudes the older gabbroic and metamorphic rocks as thin (less than $3 \mathrm{~m}$ ) dikes with sharp contacts. These dikes are composed of medium- to coarse-grained albitic plagioclase (60-75 percent), quartz (25-40 percent), and less than 10 percent mafic minerals (hornblende, chlorite, and opaque minerals). Minor amounts of white mica (paragonite?) are associated with the chlorite, and in places grossularitic garnet is present. The relatively low $\mathrm{Al}_{2} \mathrm{O}_{5}$ (13.32 wt percent), low $\mathrm{K}_{2} \mathrm{O}$ (0.99 wt percent), high $\mathrm{Na}_{2} \mathrm{O}$ (5.30 wt percent), and high $\mathrm{SiO}_{2}$ (74.55 wt percent) contents (table 1) place these rocks in the low-aluminum trondhjemite field of Barker and others (1976).

Compositional and mineralogical data do not indicate whether the trondhjemitic rocks formed from fractionation of mafic magma or quartz dioritic magma, from subsolidus alteration of quartz diorite, from partial melting of the mafic and calcareous hornfels and the gabbroic rocks, or from partial melting of the subduction melange (McHugh Complex) at depth. The trondhjemite dikes may have been emplaced in Middle to Late Jurassic time as part of the formation of the island arc or in Cretaceous time as an unrelated event. Age relationships determined from field evidence imply only that the trondhjemites are younger than the metamorphic, gabbroic, and quartz dioritic rocks of the Nelchina River Gabbronorite and older than the felsite dike unit discussed later. Trails of quartz and feldspar that have formed on the edges of metamorphic inclusions in the gabbroic rocks, the proximity of the dikes to the hornfels, and the presence of garnets within some of the dikes may indicate that the dikes formed by partial melting of the hornfels during intrusion of the gabbroic magma.

Alternatively, the trondhjemites in the Nelchina transect may correlate with trondhjemitic plutons and dikes about 30 to $50 \mathrm{~km}$ west, in the Anchorage C- 4 and C-5 quadrangles. These western trondhjemite plutons intrude Cretaceous rocks and yield K-Ar hornblende ages of 126 to $124 \mathrm{Ma}$ and a U-Pb zircon concordant date of $103 \mathrm{Ma}$ (Pavlis, 1982).

The dikes are typically altered to abundant finegrained white mica, which formed from plagioclase, and lesser amounts of chlorite and are crosscut by quartzsericite veins. The degree of quartz-sericite veining and chloritic alteration is much less than in the quartz-albite rocks that are assumed to be altered quartz diorites; this may indicate that the trondhjemites are not alteration products of normal hornblende-bearing quartz diorites.

\section{FELSITE PLUGS, DIKES, AND INTRUSIVE BRECCIAS (Tf, Tfb)}

Felsite occurs as small plugs and narrow (less than $2 \mathrm{~m}$ wide), typically orange-weathering dikes (unit Tf). The dikes are generally andesitic, but some are dacitic. Although minor amounts of aphyric felsite are present, porphyritic textures are most common; phenocrysts consist of plagioclase (5-15 percent) with minor hornblende and (or) quartz. Fine-grained feldspar laths in the groundmass are oriented, presumably owing to flow processes. A minor amount of breccia containing clasts of gabbroic rocks, quartz diorite, quartz veins, and felsite in a felsitic matrix (unit $\mathrm{Tfb}$ ) is present as intrusions into felsites (unit Tf) and gabbroic rocks (fig. 17). Also, felsite dikes (unit Tf) have intruded the felsitic-matrix intrusive breccia (unit $T f b)$.

The felsite dikes are the youngest rocks that intrude the Nelchina River Gabbronorite and are relatively undeformed. K-Ar hornblende ages from similar felsites just outside the map area yield ages of 52 to $40 \mathrm{Ma}$ (Winkler and others, 1981; Silberman and Grantz, 1984). Alteration minerals in the dikes mainly comprise calcite, chlorite, white mica, and minor pyrite.

\section{ALTERATION AND VEINING OF GABBROIC ROCKS}

Mineral assemblages characteristic of amphibolite and greenschist metamorphism are common in the gabbroic rocks of the Nelchina transect (fig. 18); the majority of these were probably produced by hydrothermal alteration during a long cooling period. Some of the greenschist 
assemblage is probably related to a younger event involving extensive deformation, which probably occurred during Cretaceous time (Pavlis, 1982). Minor amounts of zeolites also are present as late-stage fracture fillings.

\section{UPPER AND MIDDLE(?) AMPHIBOLITE ASSEMBLAGE}

High-temperature deuteric alteration is represented in the gabbroic rocks by the formation of cummingtonite/ anthophyllite (optical and microprobe determinations) from orthopyroxene; the coexisting altered orthopyroxene, calcic plagioclase, diopside, and local hornblende represent the labradorite/bytownite amphibolite facies of Winkler (1974). The cummingtonite/anthophyllite appears to be more $\mathrm{Mg}$ rich than the coexisting orthopyroxene (table 2) and typically is accompanied by minor amounts of magnetite. This assemblage and composition suggest that the cummingtonite/anthophyllite formed from a slightly oxidizing fluid. In some gabbroic rocks, plagioclase exhibits metamorphic textures but is still relatively calcic $\left(\mathrm{An}_{70}\right.$, electron microprobe data); this composition also suggests temperatures correlative with amphibolite reequilibration.

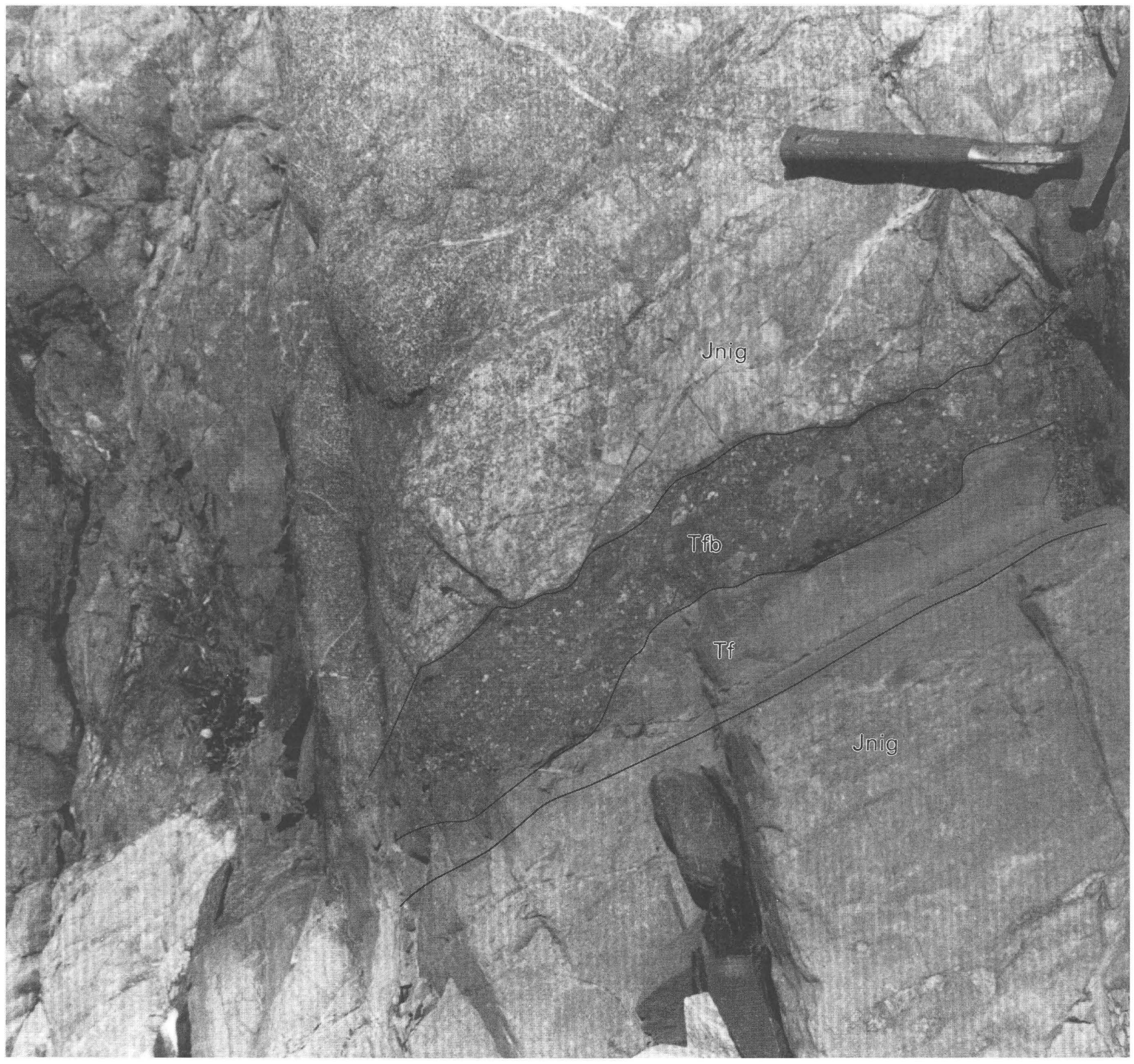

Figure 17. Felsite dike (Tf) and felsitic-matrix breccia dike (Tfb) crosscutting gabbroic rock (Jnig). Breccia contains clasts of felsite and country rock. Photograph by G.H. Pessel. 
Slightly lower temperature alteration resulted in the formation of clinozoisite from plagioclase. This assemblage, clinopyroxene-cummingtonite/anthophylliteclinozoisite-plagioclase, is common in the Nelchina River Gabbronorite.

\section{LOWER AMPHIBOLITE-UPPER GREENSCHIST ASSEMBLAGES}

Formation of clinozoisite and minor albite from plagioclase and the association of these minerals with chlorite and hornblende imply alteration at temperatures associated with lower amphibolite to possibly upper greenschist reequilibration. This alteration assemblage is superimposed on the higher temperature assemblages and probably resulted

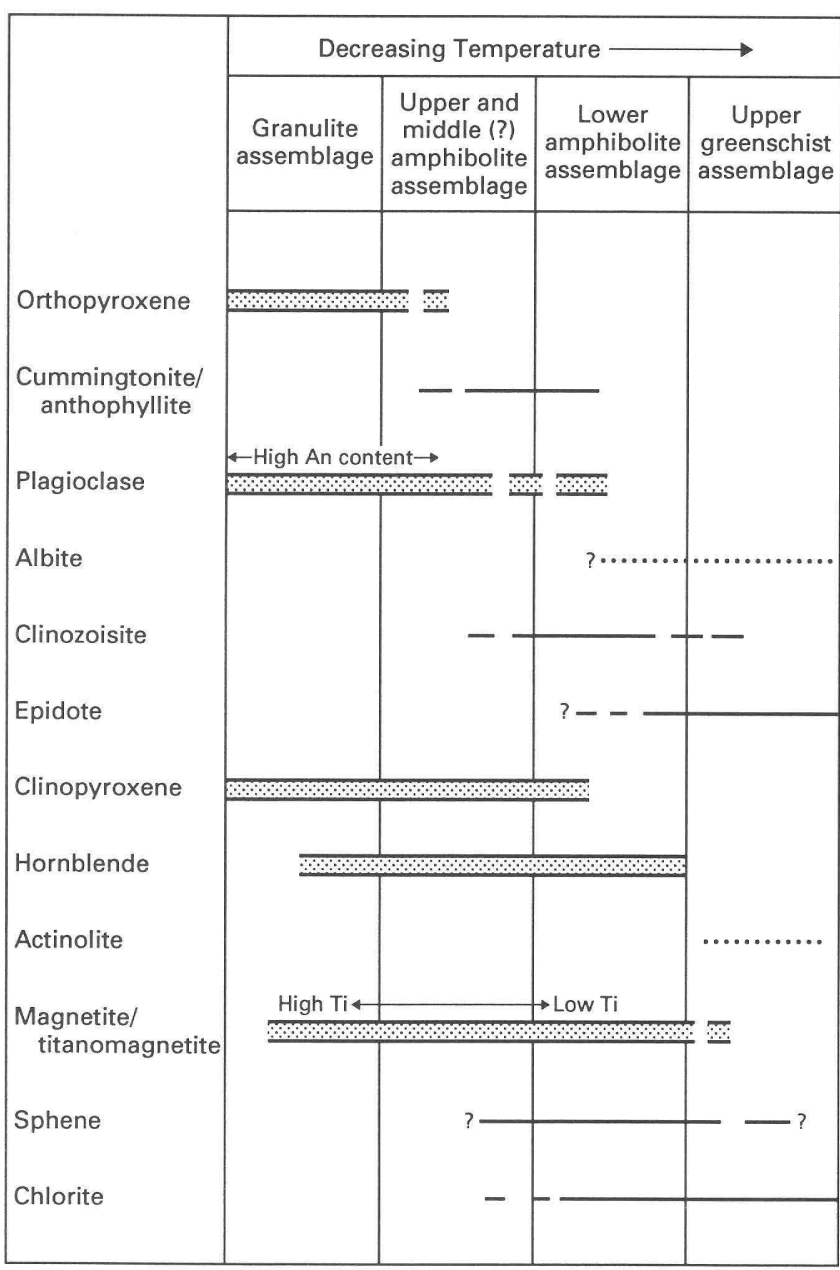

Figure 18. Major mineral assemblages of gabbroic rocks from Nelchina transect of the Nelchina River Gabbronorite. Relict, metastable primary minerals shown by stippled bars; secondary minerals shown as single lines. Dotted lines denote trace amounts of minerals; dashed lines and interrupted bars indicate uncertain extent; queries indicate further extent unknown. from decreasing temperatures during cooling of the gabbroic rocks. Sporadic, trace amounts of actinolite, generally considered to be characteristic of greenschist assemblages, are present as an alteration product of clinopyroxene in only a few rocks; also, hornblende does not alter to actinolite. This resistance of clinopyroxene and hornblende to actinolitic alteration suggests that the oxidation state of the hydrothermal fluid was high. Large amounts of actinolite, formed from the breakdown of hornblende and (or) clinopyroxene, and albite, formed from plagioclase, are abundant only in gabbroic rocks near major areas of deformation and young faults. Minor amounts of hematite are also present locally. The actinolite, albite, and hematite tend to increase in abundance toward the south.

Three of the four areas of major chloritization within the Nelchina transect are within areas of intense deformation. The podiform hornblende gabbronorite unit (Jnpg) in the dike complex is the only strongly chloritized unit with only minor deformation; access for aqueous solutions was probably provided along dike walls. However, all three levels of chloritization discussed later may represent mainly deuteric alteration, with the most-altered assemblage reflecting either a longer timespan of hydrothermal alteration or more abundant fluid per unit time. Chloritization related to a syndeformational or post-deformational event is probably present but has not been distinguished as such in the exposure.

Chloritization in the Nelchina transect can be divided into three levels of intensity: (1) minor chloritization, typically affecting only cummingtonite/anthophyllite and orthopyroxene, (2) moderate chloritization, with alteration of both pyroxenes and cummingtonite/anthophyllite to chlorite ( \pm epidote) and formation of some epidote from clinozoisite, and (3) strong chloritization, including intense alteration of cummingtonite/anthophyllite and any remaining orthopyroxene to chlorite, of magnetite to chlorite, of clinopyroxene to chlorite-epidote, and of clinozoisite to epidote. Minor veining of hornblende by chlorite is also common in the intensely chloritized gabbroic rocks.

The optical characteristics and composition of the chlorite appear to vary with the intensity of alteration. In the areas of moderate chloritization, chlorite is greenish gray to blue under crossed nicols, and the value of a mole fraction $\mathrm{Mg} /\left(\mathrm{Mg}+\mathrm{Fe}^{*}\right)$ is $0.65-0.55$. In contrast, the chlorite in the areas of strong chloritization is iron rich, with the value of a mole fraction $\mathrm{Mg} /\left(\mathrm{Mg}+\mathrm{Fe}^{*}\right)$ ranging from 0.40-0.50, and shows an anomalous purple birefringence.

The replacement of Fe-Ti oxides by pyrite and very minor chalcopyrite and the abundance of sphene and epidote tend to increase with increasing degree of chloritization. The pyrite is probably related to introduction of sulfate-rich marine waters. Epidote is commonly present between chlorite and clinozoisite and presumably formed from the clinozoisite. 


\section{ALTERATION OF GABBROIC ROCKS ASSOCIATED WITH INTRUSION OF FELSITE DIKES}

Some gabbroic rocks in the southern part of the map area weather to a dull black, which is apparently caused by fine-grained, disseminated magnetite. The typical alteration products in the gabbroic rocks surrounding these black-weathered rocks are chlorite, clinozoisite, epidote, and actinolite. Except for the addition of magnetite, no particular difference in mineralogy between the black gabbronorite and the surrounding gabbronorite can be discerned. This black-weathered unit is always near or contains small felsite dikes or felsitic-matrix intrusive breccia; this association suggests that the alteration is produced by oxidation associated with the felsite intrusions. Whether any chloritization is directly related to the felsite intrusions is not known.

\section{CARBONATE VEINS}

Carbonate veins, dominantly calcite \pm siderite(?), are also common near felsites and chloritized areas and, with the possible exception of zeolites of unknown age, are evidence of the latest stage of hydrothermal processes operating along the transect. These reddish-orange-weathering veins typically contain 1 to 5 percent pyrite and very minor amounts of base-metal sulfides. The veins generally follow major faults and in places crosscut the faults. Therefore, the observed faulting preceded the hydrothermal circulation event that produced the veins.

Weathering of pyrite contained in these carbonate veins, and to a lesser extent pyrite in the surrounding rocks, produced iron oxide that stained some of the adjacent trondhjemite dikes and quartz diorite orange. Orange staining is also present to a lesser degree in adjacent gabbroic rocks.

\section{COMPOSITIONAL RELATIONS}

The chemical compositions of rocks from the Nelchina transect (table 1), which are plotted on an AFM diagram (fig. 19), indicate that the gabbroic rocks of the Nelchina River Gabbronorite are moderately iron enriched; this enrichment reflects in a general way the amount of magnetite present. The quartz diorites follow a calc-alkaline hyperthenic trend, and the rocks from contact zones between quartz diorites and gabbroic rocks plot logically between these rock types.

The gabbroic rocks are notably high in iron and low in silica, as shown by a $\mathrm{SiO}_{2}$ versus $\mathrm{FeO}^{*} / \mathrm{MgO}$ plot (fig. 8 ). Although the gabbroic rocks mostly plot on the tholeiitic side of the diagram, they do not follow a typical tholeiitic trend, which would have a slope greater than about
0.13 . Additionally, the distinction in major-oxide compositional data between tholeiitic and calc-alkaline trends disappears at very low silica values (Kay and others, 1982). The extremely low silica values for the gabbroic rocks reflect the altered composition of the rocks; field evidence already discussed suggests that the rocks were altered during late magmatic events. Therefore, the gabbroic rocks cannot be classified as calc-alkaline or tholeiitic on the basis of this scheme.

\section{SUMMARY OF EVOLUTION OF GABBRONORITES}

Textures seen in outcrop are substantially different for the cumulate and dike gabbronorites; this contrast suggests that the two types formed by different methods of crystallization. Field relationships already discussed also suggest that at least two distinct major pulses of magma produced these two types of gabbronorite.

In the dike complex, plastic-deformation textures, a consistent sense of flow foliation produced during intrusion, and the multiple injections of gabbronorite suggest that the dike complex formed in a very dynamic part of the magma system. In contrast, the cumulus-gabbronorite section yields layers produced by quiescent processes; some flow layering, possibly due to moderate pressure during reequilibration, also may have been involved in their formation.

Field and mineralogical evidence also suggest that the dike complex formed from a slightly later pulse of magma than that from which the cumulus gabbronorite crystallized. Both coarse- and fine-grained gabbronorite dikes in the dike complex are parallel to the plastically deformed dikes in the cumulus gabbronorites in the transect and are perpendicular to the cumulus layers. Mineralogical similarities between the early gabbronorites in the dike complex and the deformed dikes in the cumulus gabbronorites-characterized by abundant magmatic hornblende, magnetite, and ilmenite-suggest that both were formed either during crystallization of a water-rich magma or by introduction of water ( \pm vapor?) while the rocks were still hot. In contrast, the cumulus gabbronorite around these plastically deformed dikes contains only small amounts of magmatic hornblende, magnetite, or ilmenite. Although the Nelchina River Gabbronorite is not continuously exposed between the dike complex and the cumulates, these deformed dikes suggest that the cumulates came from an older magma, which was later crosscut by the dike complex while the cumulates were still above the solidus temperature.

During evolution of the dike complex, successively coarser grained gabbronorite intruded the existing dikes. Introduction of water appears to have lessened over time, as the later gabbroic rocks contain much less hornblende, 


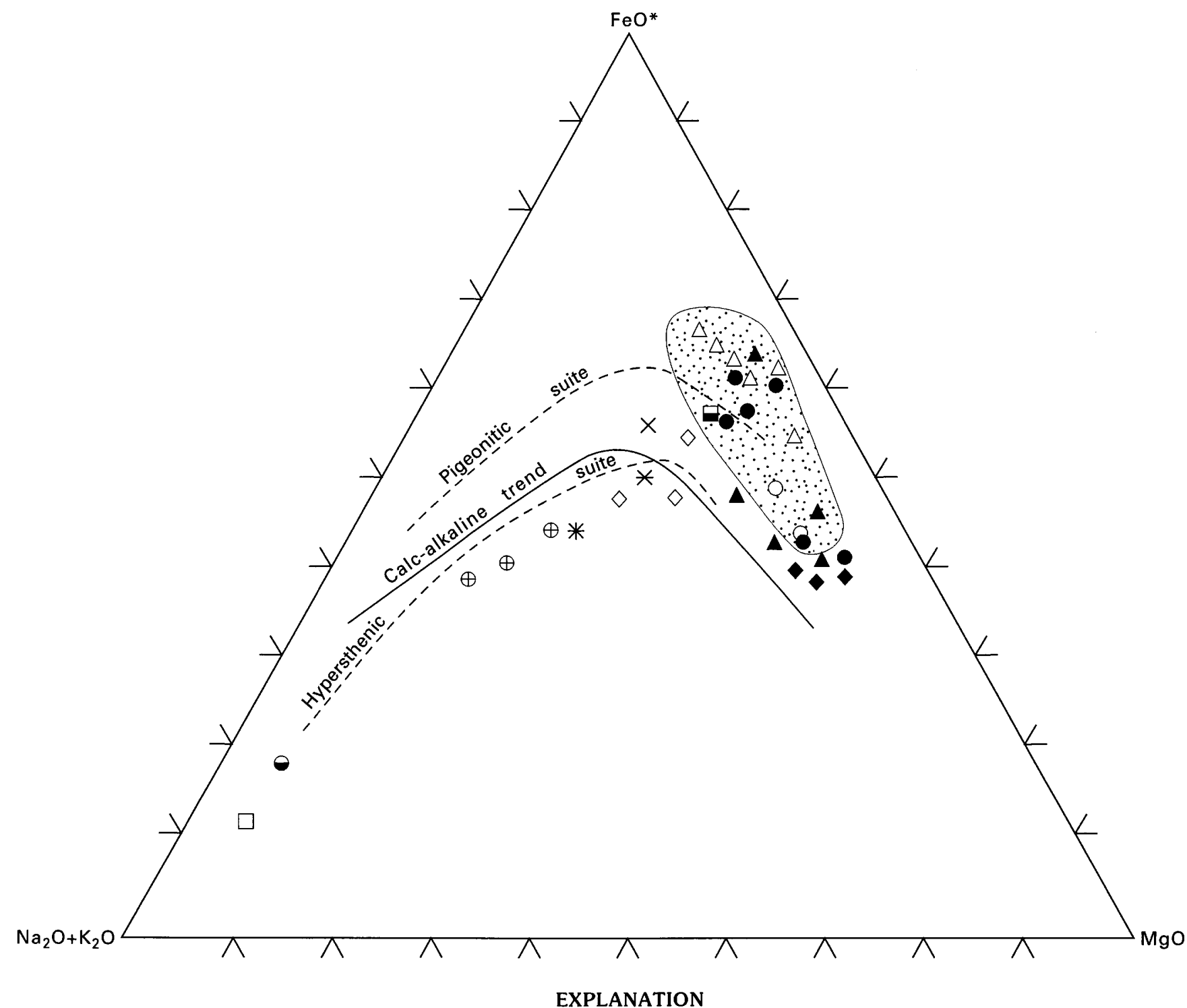

GABBRONORITE AND RELATED ROCKS

QUARTZ-RICH PLUTONIC ROCKS

Cumulus-layered gabbronorite (Jncl)
$\Delta \quad \begin{gathered}\text { Fine-grained gabbronorite (Jnfg) and podiform } \\ \text { hornblende gabbronorite (Jnpg) }\end{gathered}$
Banded gabbronorite (Jnbg)
$\Delta \quad \begin{aligned} & \text { Mixed gabbroic rocks (Jnmx) } \\ & \text { (Jnigi, Jnigd, Jnig) }\end{aligned}$
$\quad \begin{aligned} & \text { Mafic dikes (Jnmd) } \\ & \text { Mixed gabbroic rocks and quartz diorite, undivided } \\ & \text { (Jngq) }\end{aligned}$

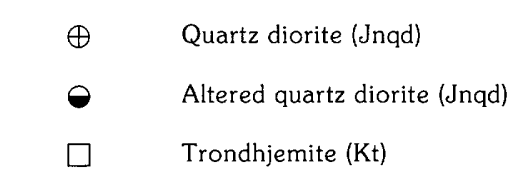

$\because \because \because \because$ ISLAND-ARC GABBROIC ROCKS

AVERAGE MAFIC ANDESITE

$\times \quad$ Low potassium

* Medium potassium

* High potassium

Figure 19. AFM diagram of gabbroic rocks and quartz diorites from the Nelchina River Gabbronorite. Cumulus-layered gabbronorites and podiform hornblende gabbronorites are from Nelchina transect and other parts of the Nelchina River Gabbronorite; all other rocks are from Nelchina transect only. Data from plutonic xenoliths in island arcs (shaded) taken from Aoki and Kuno (1972) and Meijer and Reagan (1981). Calc-alkaline trend (solid line) from Irvine and Baragar (1971). Pigeonitic and hypersthenic rock suites (dashed lines) from Kuno (1968); average andesitic composition from Gill (1981). FeO*, total iron as $\mathrm{FeO}$. 
magnetite, and ilmenite. Successive intrusions are generally thicker than preceding intrusions. Also, they appear to evolve into the isotropic gabbronorite, which crops out to the south of the dike complex; textures in the gabbronorite in the dike complex changed over time from flow-foliated dike rock to gabbronorite with a completely isotropic fabric.

\section{RELATIONSHIP OF QUARTZ DIORITE TO GABBROIC ROCKS}

The origin of the quartz diorites in the Nelchina transect is not understood. Extreme differentiation of gabbroic magma could produce quartz diorite and tonalite. Introduction of water into gabbroic magma and (or) a rise in oxygen fugacity could cause abundant $\mathrm{Fe}$-Ti oxides to crystallize and subsequently enrich the remaining magma in silica. Differentiation of the gabbroic magma as the sole process for forming the intermediate-composition plutonic rocks is suspect owing to a volume problem. The intermediate-composition plutonic rocks form about 20 to 30 percent of the plutonic rocks in the area. Additionally, possibly a quarter of the rock mapped as quartz diorite in the northern Chugach Mountains is actually granodiorite. Whether or not differentiation of the gabbroic magma could produce this amount of moderately K-rich rocks is unknown. Furthermore, rocks compositionally between gabbronorite and quartz diorite are found along the Nelchina transect, but detailed mapping indicates that these rocks formed by assimilation of still-warm gabbronorite during intrusion of the quartz diorite. No rock with textures suggesting crystallization from only one magma was found to be compositionally and (or) mineralogically in between the gabbroic rocks and the intermediate-composition rocks, but this intermediate rock type may exist elsewhere in the Nelchina River Gabbronorite. Another means of producing the calc-alkaline quartz diorite entails partial melting of a different source of either mantle or relict oceanic-crust origin.

\section{CONCLUSIONS}

Detailed mapping of the rocks along the Nelchina transect reveals that most of the layering observed formed from multiple intrusions. Field relationships generally attributed to classic layered sequences-including modally graded layers, size-graded layers, phase layering, and wispy layering-formed in the dike complex near the Nelchina Glacier as a result of multiple intrusion and probable flow. Crosscutting dikes also resemble erosional unconformities which are typically thought to represent magmatic currents. Whether the contacts among the dikes in the dike complex are sharp or diffuse is apparently related to the amount of new magma supplied and to differences in the relative temperatures of the magma and the gabbroic rocks. The warmer the host rocks, the more diffuse the contacts of the dikes.

The Nelchina River Gabbronorite had to evolve, at least in part, in a dynamic environment, where magmas of various compositions were produced. Evidence in the rocks of the Nelchina transect suggests that the dike complex crosscuts the cumulus-layered section and that the gabbronorite formed from several intrusions of mafic magma. Textural relations indicate that all intrusions occurred within a relatively short time interval. Slightly later intrusions of quartz dioritic magmas were produced by (1) differentiation of the gabbroic magma, (2) drastic change in composition of the magma, possibly by the introduction of water near the magma source or by stoping and assimilation of sedimentary rocks, or (3) generation of the quartz diorite magma from a different source. The last option would have to be accomplished by a smaller degree of partial melting than is involved in the process that produced the gabbroic magma. Thus, detailed field mapping of the Nelchina transect has provided insight into possible processes that formed (1) layers in an open maficmagma system and (2) part of the plutonic component of an intraoceanic island arc.

\section{REFERENCES CITED}

Alaska Division of Geological and Geophysical Surveys, 1973, Aeromagnetic map of the Anchorage quadrangle (D1-D8): ADGGS Department of Natural Resources Alaska OpenFile Report 21, scale 1:250,000, 1 map with 5 p. of text.

Andreasen, G.E., Grantz, Arthur, Zietz, Isidore, and Barnes, D.F., 1964, Geologic interpretation of magnetic and gravity data in the Copper River Basin, Alaska: U.S. Geological Survey Professional Paper 316-H, p. 135-153, with 2 map plates, scale 1:250,000.

Aoki, Ken-Ichiro, and Kuno, Hisashi, 1972, Gabbro-quartz diorite inclusions from Izu-Hakone region, Japan: Bulletin Volcanologique, v. 36, p. 164-173.

Barker, Fred, Arth, J.G., Peterman, Z.E., and Friedman, Irving, 1976, The 1.7- to 1.8-b.y.-old trondhjemite-basalt suite of southwestern Colorado and northern New Mexico-Geochemistry and depths of genesis: Geological Society of America Bulletin, v. 87, p. 189-198.

Barker, Fred, and Grantz, Arthur, 1982, Talkeetna Formation in the southeastern Talkeetna Mountains, southern Alaska-An Early Jurassic andesitic island arc [abs]: Geological Society of America Abstracts with Programs, v. 14, p. 147.

Barnes, D.F., 1977, Gravity map of southern Alaska, eastern part: U.S. Geological Survey Open-File Report 77-169C, scale $1: 1,000,000$.

Buddington, A.F., 1959, Granite emplacement with special reference to North America: Geological Society of America Bulletin, v. 70, p. 671-747. 
Burns, L.E., 1982, Gravity and aeromagnetic modeling of a large gabbroic body near the Border Ranges fault, southern Alaska: U.S. Geological Survey Open-File Report 82-460, 72 p., with 3 map plates, scale 1:250,000.

1983, The Border Ranges mafic complex, southern Alaska-Plutonic core of an intraoceanic island arc: Ph.D. dissertation, Stanford University, Stanford, California, $150 \mathrm{p}$.

1985, The Border Ranges ultramafic and mafic complex, south-central Alaska-Cumulate fractionates of island-arc volcanics: Canada Journal of Earth Science, v. 22, p. 1020-1038.

Burns, L.E., Little, T.A., Newberry, R.J., Decker, J.E., Pessel, G.H., 1983, Preliminary geologic map of parts of the Anchorage C-2, C-3, D-2, and D-3 quadrangles, Alaska: Alaska Division of Geological and Geophysical Surveys Report 83-10, scale 1:25,000, 3 sheets.

Carden, J.R., and Decker, J.E., 1977, Tectonic significance of the Knik River Schist terrane, south-central Alaska: State of Alaska Department of Natural Resources, Division of Geological and Geophysical Surveys Geologic Report 55, p. 7-9.

Case, J.E., Burns, L.E., and Winkler, G.R., 1985, Maps showing aeromagnetic survey and geologic interpretation of the Valdez quadrangle, Alaska: U.S. Geological Survey Miscellaneous Field Studies Map MF-1714, scale 1:250,000, 4 sheets.

Clark, S.H.B., 1972, Reconnaissance bedrock geologic map of the Chugach Mountains near Anchorage, Alaska: U.S. Geological Survey Miscellaneous Field Studies Map MF350 , scale 1:63,360.

Gill, J.B., 1981, Orogenic andesites and plate tectonics: New York, Springer-Verlag, 390 p.

Grantz, Arthur, 1960, Generalized geologic map of the Nelchina area, Alaska, showing igneous rocks and larger faults: U.S. Geological Survey Miscellaneous Geologic Investigations Map I-312, scale 1:96,000.

1961a, Geologic map and crosssections of the Anchorage (D-2) quadrangle and northeasternmost part of the Anchorage (D-3) quadrangle, Alaska: U.S. Geological Survey Miscellaneous Geologic Investigations Map I-342, scale $1: 48,000$.

1961b, Geologic map of the north two-thirds of Anchorage (D-1) quadrangle, Alaska: U.S. Geological Survey Miscellaneous Geologic Investigations Map I-343, scale $1: 48,000$.

1965, Geologic map and cross sections of the Nelchina area, south-central Alaska: U.S. Geological Survey openfile report 255 , scale $1: 48,000,4$ sheets.

Irvine, T.N., 1982, Terminology for layered intrusions: Journal of Petrology, v. 23, p. 127-162.

Irvine, T.N., and Baragar, W.R.A., 1971, A guide to the chemical classification of the common volcanic rocks: Canadian Journal of Earth Science, v. 8, p. 523-548.

Jones, D.L., Silberling, N.J., Berg, H.C., and Plafker, George, 1981, Map showing tectono-stratigraphic terranes of Alaska, columnar sections, and summary description of terranes: U.S. Geological Survey Open-File Report 81-792, scale $1: 2,500,000,2$ map sheets with 20 p. of text.
Kay, S.M., Kay, R.W., and Citron, G.P., 1982, Tectonic controls on tholeiitic and calc-alkaline magmatism in the Aleutian Arc: Journal of Geophysical Research, v. 87,p. 4051-4072.

Kuno, Hisashi, 1968, Differentiation of basalt magmas, in Hess, H.H., Poldervaart, Arnie, eds., Basalts: New York, WileyInterscience, p. 623-688.

MacKevett, E.M., Jr., 1976, Geologic map of the McCarthy quadrangle, Alaska: U.S. Geological Survey Miscellaneous Field Studies Map MF-773-A, scale 1:250,000.

Mehnert, K.R., 1968, Migmatites and the origin of granitic rocks: New York, Elsevier, 393 p.

Meijer, Arend, and Reagan, Mark, 1981, Petrology and geochemistry of the island of Sarigan in the Mariana arc-Calc-alkaline volcanism in an oceanic setting: Contributions to Mineralogy and Petrology, v. 77 , p. 337-354.

Miyashiro, Akiho, 1974, Volcanic-rock series in island arcs and active continental margins: American Journal of Science, v. 274 , p. $321-355$.

Newberry, R.J., Burns, L.E., and Pessel, G.H., 1986, Volcanogenic massive-sulfide deposits and the "missing complement" to the calc-alkaline trend-Evidence from the Jurassic Talkeetna island arc of southern Alaska: Economic Geology, v. 81, p. 951-960.

Pavlis, T.L., 1982, Origin and age of the Border Ranges fault of southern Alaska and its bearing on the late Mesozoic tectonic evolution of Alaska: Tectonics, v. 1, no. 4, p. 343368.

Pessel, G.H., Henning, M.W., and Burns, L.E., 1981, Preliminary geologic map of parts of the Anchorage C-1, C-2, D1, and D-2 quadrangles, Alaska: Alaska Division of Geological and Geophysical Surveys Open-File Report AOF-121, scale $1: 63,360$.

Plafker, George, Jones, D.L., Pessagno, E.A., Jr., 1977, A Cretaceous accretionary flysch and melange terrane along the Gulf of Alaska margin, in Blean, K.M., ed., The U.S. Geological Survey in Alaska-Accomplishments during 1976: U.S. Geological Survey Circular 751-B, p. B41-B43.

Plafker, George, Nokleberg, W.J., and Lull, J.S., 1985, Summary of 1984 TACT geologic studies in the northern Chugach Mountains and southern Copper River Basin, in BartschWinkler, Susan, ed., The U.S. Geological Survey in AlaskaAccomplishments during 1984: U.S. Geological Survey Circular 967, p. 76-79.

Silberman, M.L., and Grantz, Arthur, 1984, Paleogene volcanic rocks of the Matanuska Valley area and the displacement history of the Castle Mountain fault, in Coonrad, W.L., and Elliott, R.L., eds., The U.S. Geological Survey in AlaskaAccomplishments during 1981: U.S. Geological Survey Circular 868 , p. 82-86.

Streckeisen, Albert, 1976, To each plutonic rock its proper name: Earth Science Reviews, v. 12, p. 1-33.

U.S. Geological Survey, 1979, Aeromagnetic map of part of the Valdez $1^{\circ}$ by $3^{\circ}$ quadrangle, Alaska: U.S. Geological Survey Open-File Report 79-381, scale 1:250,000.

Winkler, H.G.F., 1974, Petrogenesis of metamorphic rocks (4th ed.): New York, Springer-Verlag, 334 p.

Winkler, G.R., Silberman, M.L., Grantz, Arthur, Miller, R.J., and MacKevett, E.M., Jr., 1981, Geologic map and summary geochronology of the Valdez quadrangle, southern Alaska: U.S. Geological Survey Open-File Report 80-892A, scale 1:250,000, 2 sheets. 
Table 1. Major-oxide chemical analyses of and CIPW norms for gabbroic rocks, mafic dikes, quartz diorites, trondhjemites, and felsites from the Nelchina River Gabbronorite.

[Chemical analyses were determined by XRF, with the exception of FeO which was done by titration (analyses by N.C. Veach and Kate Bull of the Alaska Division of Geological and Geophysical Surveys (aboratory). Fe0*, total iron as $\mathrm{FeO}$; $\mathrm{A}$, $\left(\mathrm{Na}_{2} \mathrm{O}+\mathrm{K}_{2} \mathrm{O}\right) /\left(\mathrm{Na}_{2} \mathrm{O}+\mathrm{K}_{2} \mathrm{O}+\mathrm{FeO} \mathrm{O}^{*}+\mathrm{MgO}\right) ; \quad \mathrm{F}, \mathrm{FeO}^{*} /\left(\mathrm{Na}_{2} \mathrm{O}+\mathrm{K}_{2} \mathrm{O}+\mathrm{FeO} *+\mathrm{MgO}^{2}\right.$; $M$, $\mathrm{MgO} /\left(\mathrm{Na}_{2} \mathrm{O}+\mathrm{K}_{2} \mathrm{O}+\mathrm{FeO}^{\star}+\mathrm{MgO}\right)$; -.-, not applicable or none; norm An, an/(an+ab+or); norm $A b, a b /(a n+a b+o r)$; norm or, or/(an+ab+or). Units mentioned in footnotes refer to map units on pl. 1]

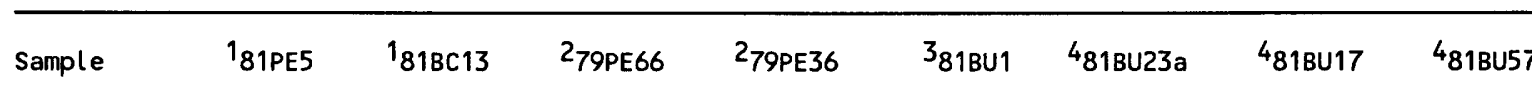

Chemical analyses (weight percent)

\begin{tabular}{|c|c|c|c|c|c|c|c|c|}
\hline $\mathrm{SiO}_{2} \cdots \cdots$ & 44.69 & 46.93 & 40.04 & 46.74 & 43.48 & 40.76 & 40.77 & 40.90 \\
\hline $\mathrm{Al}_{2} \mathrm{O}_{3} \ldots$ & 22.63 & 18.63 & 16.83 & 18.16 & 20.13 & 18.54 & 17.26 & 17.77 \\
\hline Feo & 3.96 & 7.63 & 9.43 & 5.66 & 6.93 & 9.41 & 10.10 & 8.48 \\
\hline $\mathrm{Fe}_{2} \mathrm{O}_{3}$ & 2.97 & 4.20 & 7.75 & 4.35 & 6.00 & 6.13 & 6.74 & 6.59 \\
\hline Mgo $\ldots . . . . . . .$. & 7.97 & 7.11 & 7.49 & 5.44 & 5.89 & 6.68 & 7.73 & 7.31 \\
\hline CaO & 14.85 & 11.83 & 12.31 & 11.10 & 11.45 & 12.79 & 11.94 & 14.19 \\
\hline $\mathrm{Na}_{2} \mathrm{O} \cdots$ & 1.08 & 2.04 & 1.23 & 2.61 & 2.10 & 1.06 & 1.41 & .65 \\
\hline$K_{2} \mathrm{O} \cdots$ & .10 & .05 & .04 & .12 & .04 & $\cdots$ & .04 & $\cdots$ \\
\hline $\mathrm{H}_{2} \mathrm{O}^{+} \ldots$ & 1.19 & .61 & 2.36 & 3.86 & 1.17 & 2.12 & 1.51 & 2.06 \\
\hline $\mathrm{H}_{2} \mathrm{O}^{-} \cdots$ & .16 & .14 & .11 & .10 & .48 & .53 & .49 & .68 \\
\hline $\mathrm{TiO}_{2} \cdots$ & .15 & .85 & 1.19 & .82 & 1.04 & 1.26 & 1.34 & 1.04 \\
\hline $\mathrm{P}_{2} \mathrm{O}_{5} \ldots$ & .06 & .11 & .06 & .12 & .18 & .08 & .09 & .07 \\
\hline Mno - - & .11 & .21 & .22 & .19 & .27 & .26 & .29 & .16 \\
\hline Total -- & 99.92 & 100.34 & 99.06 & 99.27 & 99.16 & 99.62 & 99.71 & 99.90 \\
\hline $\mathrm{FeO} / \mathrm{MgO}$ & 0.8 & 1.6 & 2.2 & 1.8 & 2.1 & 2.2 & 2.1 & 2.0 \\
\hline $\mathrm{Na}_{2} \mathrm{O}+\mathrm{K}_{2} \mathrm{O} \cdots$ & 1.18 & 2.09 & 1.27 & 2.73 & 2.14 & 1.06 & 1.45 & .65 \\
\hline$A-\ldots$ & 7.5 & 10.1 & 5.0 & 15.4 & 10.5 & 4.7 & 5.7 & 2.9 \\
\hline$F$ & 41.9 & 55.3 & 65.2 & 53.9 & 60.5 & 65.8 & 63.8 & 64.4 \\
\hline$M \cdots \ldots$ & 50.6 & 34.5 & 29.8 & 30.7 & 28.9 & 29.5 & 30.5 & 32.7 \\
\hline
\end{tabular}

CIPW norms (weight percent)

\begin{tabular}{|c|c|c|c|c|c|c|c|c|}
\hline$Q$ & --- & $\ldots$ & $\ldots$ & 0.6 & $\cdots$ & -- & -- & $\cdots$ \\
\hline or & 0.6 & 0.3 & 0.2 & .7 & 0.2 & $\ldots$ & 0.2 & -- \\
\hline$a b \cdots$ & 9.3 & 17.3 & 10.8 & 23.2 & 18.2 & 9.2 & 12.2 & 5.7 \\
\hline an & 57.4 & 41.7 & 41.7 & 39.3 & 46.5 & 47.3 & 41.6 & 46.9 \\
\hline ne & -.. & $\ldots$ & $\ldots$ & $\ldots$ & $\ldots$ & $\ldots$ & -- & -- \\
\hline di & 13.5 & 13.4 & 17.1 & 14.2 & 8.5 & 14.4 & 15.0 & 20.3 \\
\hline wo & $\cdots$ &.-- & -- & -- & -- & -- & $\cdots$ & $\cdots$ \\
\hline hy - . & 4.0 & 15.2 & 3.8 & 13.4 & 8.6 & 7.1 & 2.6 & 7.9 \\
\hline ol -......... & 10.4 & 4.1 & 12.2 & -- & 6.6 & 10.2 & 15.5 & 7.2 \\
\hline$m t \cdots$ & 4.4 & 6.1 & 11.6 & 6.6 & 8.9 & 9.2 & 10.0 & 9.8 \\
\hline il & .3 & 1.6 & 2.3 & 1.6 & 2.0 & 2.5 & 2.6 & 2.0 \\
\hline ap $\cdots$ & .1 & .3 & .1 & .3 & .4 & .2 & .2 & .2 \\
\hline cor & -- & -- & $\cdots$ & -- & $\cdots$ & -- & -- & $\cdots$ \\
\hline Norm An $\ldots$ & 85.3 & 70.3 & 79.1 & 62.2 & 71.6 & 83.6 & 77.0 & 89.2 \\
\hline Norm Ab & 13.8 & 29.2 & 20.4 & 36.6 & 28.0 & 16.4 & 22.6 & 10.8 \\
\hline Norm Or & .9 & .5 & .5 & 1.2 & .4 &.- & .4 & $\cdots$ \\
\hline
\end{tabular}

${ }_{1}^{1}$ Cumulus-layered gabbronorite (unit Jnclg), Barnette Creek.

${ }_{3}^{2}$ Cumulus-layered gabbronorite (unit Jnclg), Nelchina transect.

3 Fine-grained hornblende gabbronorite (unit $\mathrm{Jnfg}$ ), Nelchina transect. 
Table 1. Major-oxide chemical analyses of and CIPW norms for gabbroic rocks, mafic dikes, quartz diorites, trondhjemites, and felsites from the Nelchina River Gabbronorite-Continued

\begin{tabular}{lllllllll}
\hline Sample & $5_{81 \mathrm{BU} 19}$ & $5_{81 \mathrm{BU} 58}$ & $681 \mathrm{BU} 46$ & $7_{81 \mathrm{BU} 108}$ & $8_{81 \mathrm{BU} 3}$ & $9_{81 \mathrm{BU} 21 \mathrm{a}}$ & $9_{81 \mathrm{BU} 64}$ & $1081 \mathrm{BU} 53$
\end{tabular}

Chemical analyses (weight percent)

\begin{tabular}{|c|c|c|c|c|c|c|c|c|}
\hline $\mathrm{siO}_{2} \cdots \cdots$ & 41.25 & 42.20 & 44.45 & 45.98 & 48.00 & 43.36 & 45.04 & 47.38 \\
\hline $\mathrm{Al}_{2} \mathrm{O}_{3} \ldots$ & 18.39 & 17.64 & 20.28 & 18.28 & 16.18 & 23.28 & 20.39 & 18.38 \\
\hline FeO & 8.91 & 7.52 & 7.52 & 6.42 & 7.02 & 4.44 & 5.75 & 4.59 \\
\hline $\mathrm{Fe}_{2} \mathrm{O}_{3} \ldots$ & 5.79 & 5.09 & 4.04 & 3.53 & 2.63 & 3.15 & 2.46 & 2.54 \\
\hline MgO - & 7.18 & 8.35 & 5.23 & 7.36 & 9.90 & 5.52 & 7.35 & 7.82 \\
\hline $\mathrm{CaO} \ldots$ & 13.12 & 14.09 & 10.89 & 12.18 & 10.47 & 13.01 & 12.90 & 14.22 \\
\hline $\mathrm{Na}_{2} \mathrm{O} \cdots$ & 1.30 & .97 & 2.62 & 2.07 & 2.06 & 2.06 & 1.77 & 1.43 \\
\hline $\mathrm{K}_{2} \mathrm{O} \ldots$ & $\cdots$ & .01 & .12 & .05 & .19 & .07 & .13 & .08 \\
\hline $\mathrm{H}_{2} \mathrm{O}^{+} \ldots \ldots$ & 1.92 & 1.83 & 2.01 & 2.12 & 1.54 & 3.07 & 1.78 & 1.66 \\
\hline $\mathrm{H}_{2} \mathrm{O}^{-} \cdots \cdots$ & .49 & .73 & .65 & .65 & .62 & .47 & .67 & .70 \\
\hline $\mathrm{TiO}_{2} \ldots \ldots$ & 1.09 & .66 & 1.01 & .79 & .63 & .58 & .74 & .36 \\
\hline$P_{2} \mathrm{O}_{5} \ldots \ldots$ & .07 & .08 & .27 & .09 & .07 & .05 & .08 & .09 \\
\hline Mno $\ldots$ & .24 & .15 & .12 & .20 & .19 & .14 & .23 & .16 \\
\hline Total .... & 99.75 & 99.32 & 99.21 & 99.72 & 99.50 & 99.20 & 99.29 & 99.41 \\
\hline $\mathrm{FeO} / \mathrm{MgO} \ldots$ & 2.0 & 1.4 & 2.1 & 1.3 & 0.9 & 1.3 & 1.1 & 0.9 \\
\hline $\mathrm{Na}_{2} \mathrm{O}+\mathrm{K}_{2} \mathrm{O} \cdots$ & 1.30 & .98 & 2.74 & 2.12 & 2.25 & 2.13 & 1.90 & 1.51 \\
\hline$A \cdots$ & 5.8 & 4.6 & 10.5 & 11.1 & 10.4 & 14.3 & 10.5 & 9.3 \\
\hline F & 62.5 & 56.4 & 60.5 & 50.3 & 43.6 & 48.7 & 60.5 & 42.4 \\
\hline M & 31.8 & 39.0 & 28.9 & 38.6 & 46.0 & 37.0 & 28.9 & 48.3 \\
\hline
\end{tabular}

CIPW norms (weight percent)

\begin{tabular}{|c|c|c|c|c|c|c|c|}
\hline Q $\cdots \cdots \cdots$ & $\cdots$ & $-\cdot$ & $\cdots$ & $\cdots$ & -- & $\cdots$ & 0.3 \\
\hline or & 0.1 & 0.7 & 0.3 & 1.2 & 0.4 & 0.8 & .5 \\
\hline$a b \ldots \ldots-11.3$ & 8.5 & 23.0 & 18.1 & 17.9 & 16.5 & 15.5 & 12.4 \\
\hline an $\ldots \ldots-15.6$ & 45.2 & 44.8 & 41.7 & 35.3 & 56.5 & 48.9 & 44.6 \\
\hline ne-n-nen & -- & -- & -- & -- & .9 & -- & $\cdots$ \\
\hline di $\ldots \ldots .916 .9$ & 21.3 & 7.7 & 16.1 & 14.2 & 8.5 & 13.5 & 21.7 \\
\hline wo & $\cdots$ & $\cdots$ & $\cdots$ & $\cdots$ & -- & $\cdots$ & -- \\
\hline hy $\ldots \ldots \ldots-1.1$ & 4.1 & 4.6 & 10.1 & 19.3 & $\cdots$ & 5.0 & 15.8 \\
\hline ol $\ldots \ldots+14.2$ & 11.7 & 10.6 & 6.7 & 6.8 & 11.1 & 11.1 & $\cdots$ \\
\hline$m t \cdots n-8.6$ & 7.6 & 6.1 & 5.3 & 3.9 & 4.8 & 3.7 & 3.8 \\
\hline$i l \ldots \ldots \ldots .1$ & 1.3 & 2.0 & 1.5 & 1.2 & 1.2 & 1.5 & .7 \\
\hline ap $\cdots \cdots$ & .2 & .6 & .2 & .2 & .1 & .2 & .2 \\
\hline cor $-\cdots+-1, \quad \cdots$ & -- & $\cdots$ & -- & -- & $\cdots$ & -- & $\cdots$ \\
\hline Norm An-... 80.1 & 84.1 & 65.4 & 69.4 & 64.9 & 76.9 & 75.0 & 77.6 \\
\hline Norm Ab_... 19.9 & 15.8 & 33.5 & 30.1 & 33.0 & 22.5 & 23.8 & 21.6 \\
\hline Norm Or - & .1 & 1.1 & .5 & 2.1 & .6 & 1.2 & .8 \\
\hline
\end{tabular}

\footnotetext{
5 Podiform hornblende gabbronorite (unit Jnpg), Nelchina transect.

6 Banded gabbronorite (unit Jnbg), Nelchina transect.

7 Mixed gabbronorite (unit Jnmx), Nelchina transect.

${ }^{8}$ Isotropic gabbronorite dikes (unit Jnigd), Nelchina transect.

9 Isotropic gabbronorite (unit Jnig), Nelchina transect.

10 I sotropic gabbronorite (unit Jnig) contaminated by quartz diorite (unit Jnqd), Nelchina transect.
} 
Table 1. Major-oxide chemical analyses of and CIPW norms for gabbroic rocks, mafic dikes, quartz diorites, trondhjemites, and felsites from the Nelchina River Gabbronorite-Continued

\begin{tabular}{|c|c|c|c|c|c|c|c|c|}
\hline Sample & $1181 \mathrm{BU} 123$ & ${ }^{11} 81 \mathrm{BU} 48$ & $11_{81 B U 85}$ & $12818 \cup 50 a$ & 1381BU89 & $13818 U 29$ & $13818 \cup 8$ & $1481 B \cup 87$ \\
\hline \multicolumn{9}{|c|}{ Chemical analyses (weight percent) } \\
\hline $\mathrm{SiO}_{2} \ldots \ldots$ & 47.70 & 48.49 & 48.95 & 56.88 & 64.96 & 65.71 & 66.65 & 74.39 \\
\hline $\mathrm{Al}_{2} \mathrm{O}_{3} \ldots$ & 13.73 & 13.96 & 15.92 & 17.44 & 14.49 & 15.43 & 15.13 & 11.63 \\
\hline $\mathrm{FeO} \ldots$ & 7.02 & 6.59 & 7.34 & 3.85 & 3.38 & 2.48 & 2.64 & .69 \\
\hline $\mathrm{Fe}_{2} \mathrm{O}_{3}$ & 2.41 & 3.03 & 1.83 & 3.20 & 2.72 & 2.67 & 1.97 & .71 \\
\hline 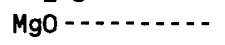 & 10.54 & 12.07 & 9.05 & 3.50 & 2.38 & 1.94 & 1.54 & .40 \\
\hline $\mathrm{CaO} \ldots \ldots$ & 11.72 & 10.41 & 9.94 & 8.28 & 4.33 & 4.83 & 4.46 & 2.63 \\
\hline $\mathrm{Na}_{2} \mathrm{O} \ldots \ldots$ & 1.95 & 2.08 & 2.30 & 3.34 & 3.90 & 4.17 & 4.26 & 4.91 \\
\hline$K_{2} \mathrm{O} \cdots$ & .43 & .13 & .42 & .17 & .22 & .35 & .20 & .26 \\
\hline $\mathrm{H}_{2} \mathrm{O}^{+} \ldots$ & 2.23 & 1.40 & 1.80 & .78 & 1.38 & .77 & 1.04 & 3.11 \\
\hline $\mathrm{H}_{2} \mathrm{O}^{-} \ldots \ldots$ & .74 & .65 & .79 & .60 & .58 & .51 & .51 & .68 \\
\hline $\mathrm{TiO}_{2} \ldots \ldots$ & .63 & .56 & .65 & .64 & .74 & .65 & .53 & .30 \\
\hline $\mathrm{P}_{2} \mathrm{O}_{5} \cdots \cdots$ & .11 & .11 & .12 & .14 & .22 & .19 & .15 & .08 \\
\hline Mno - . - & .20 & .18 & .18 & .16 & .17 & .12 & .15 & .03 \\
\hline Total - - - & 99.41 & 99.66 & 99.29 & 98.98 & 99.47 & 99.82 & 99.23 & 99.82 \\
\hline $\mathrm{FeO} / \mathrm{MgO} \ldots$ & 0.9 & 0.8 & 1.0 & 1.9 & 2.5 & 2.5 & 2.9 & 3.3 \\
\hline $\mathrm{Na}_{2} \mathrm{O}+\mathrm{K}_{2} \mathrm{O} \cdots$ & 2.38 & 2.21 & 2.72 & 3.51 & 4.12 & 4.52 & 4.46 & 5.17 \\
\hline A $\ldots$ & 10.8 & 9.4 & 13.1 & 25.6 & 33.4 & 39.9 & 42.8 & 75.0 \\
\hline$F \cdots$ & 41.5 & 39.5 & 43.3 & 49.0 & 47.3 & 43.0 & 42.4 & 19.2 \\
\hline 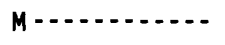 & 47.7 & 51.2 & 43.6 & 25.5 & 19.3 & 17.1 & 14.8 & 5.8 \\
\hline
\end{tabular}

CIPW norms (weight percent)

\begin{tabular}{|c|c|c|c|c|c|c|c|c|}
\hline$Q \cdots$ & --- & -- & -- & 14.7 & 28.6 & 27.2 & 29.2 & 41.1 \\
\hline or & 2.6 & 0.8 & 2.6 & 1.0 & 1.3 & 2.1 & 1.2 & 1.6 \\
\hline$a b \ldots \ldots$ & 17.1 & 18.0 & 20.1 & 29.0 & 33.8 & 35.8 & 36.9 & 43.3 \\
\hline an & 28.5 & 29.1 & 33.0 & 32.9 & 20.6 & 22.7 & 21.6 & 9.3 \\
\hline ne & $\cdots$ & $\cdots$ & $\cdots$ & $\cdots$ & $\cdots$ & $\cdots$ & -- & -- \\
\hline di $\ldots$ & 25.0 & 18.5 & 13.9 & 6.7 & $\ldots$ & .3 &.- & 2.7 \\
\hline wo & $\cdots$ &.- & -- & $\ldots$ & $\ldots$ &.- & -.. & .1 \\
\hline hy $-\ldots$ & 11.0 & 19.2 & 20.7 & 9.5 & 9.2 & 6.3 & 6.6 & $\ldots$ \\
\hline ol $\cdots \cdots+\ldots$ & 10.7 & 8.6 & 5.4 & -- & -- & $\cdots$ & -- & $\cdots$ \\
\hline$m t \cdots$ & 3.6 & 4.5 & 2.7 & 4.8 & 4.0 & 3.9 & 2.9 & 1.1 \\
\hline il & 1.2 & 1.1 & 1.3 & 1.2 & 1.4 & 1.3 & 1.0 & .6 \\
\hline ap $\ldots \ldots$ & .3 & .3 & .3 & .3 & .5 & .4 & .4 & .2 \\
\hline cor & -- & -- & $\cdots$ & --- & .5 & $\cdots$ & .2 & $\cdots$ \\
\hline Norm An $\ldots . .$. & 59.0 & 60.7 & 59.2 & 52.3 & 36.9 & 5.9 & 36.2 & 17.2 \\
\hline Norm Ab $\ldots$ & 35.5 & 37.7 & 36.2 & 46.1 & 60.7 & 93.5 & 61.7 & 79.9 \\
\hline Norm Or & 5.5 & 1.6 & 4.6 & 1.6 & 2.4 & .5 & 2.0 & 3.0 \\
\hline
\end{tabular}

\footnotetext{
11 Mafic dike (unit Jnmd), Nelchina transect.

12 Quartz diorite mixed with gabbroic rocks (unit $\mathrm{Jngq}_{1-4}$ ), Nelchina transect.

13 Quartz diorite (unit Jnqd), Nelchina transect.

${ }_{14} \mathrm{Altered}$ quartz diorite (unit Jnqd), Nelchina transect.
} 
Table 1. Major-oxide chemical analyses of and CIPW norms for gabbroic rocks, mafic dikes, quartz diorites, trondhjemites, and felsites from the Nelchina River Gabbronorite-Continued

\begin{tabular}{lll}
\hline Sample & 1581 BU135 & $16_{81 B U 82}$ \\
\hline
\end{tabular}

Chemical analyses (weight percent)

\begin{tabular}{|c|c|c|}
\hline $\mathrm{SiO}_{2} \ldots \ldots$ & 74.55 & 60.97 \\
\hline $\mathrm{Al}_{2} \mathrm{O}_{3} \ldots$ & 13.32 & 14.73 \\
\hline Feo - . & .54 & 2.27 \\
\hline $\mathrm{Fe}_{2} \mathrm{O}_{3} \ldots \ldots$ & .28 & 1.42 \\
\hline MgO-- & .49 & 1.82 \\
\hline CaO $\ldots$ & 1.44 & 6.8 \\
\hline $\mathrm{Na}_{2} \mathrm{O} \cdots \cdots$ & 5.30 & 4.13 \\
\hline$K_{2} \mathrm{O} \ldots$ & .99 & .55 \\
\hline $\mathrm{H}_{2} \mathrm{O}^{+} \ldots \ldots$ & 1.24 & 4.54 \\
\hline $\mathrm{H}_{2} \mathrm{O}^{-} \cdots$ & .66 & .97 \\
\hline $\mathrm{TiO}_{2} \ldots \ldots$ & .10 & .41 \\
\hline $\mathrm{P}_{2} \mathrm{O}_{5} \ldots \ldots \ldots$ & .07 & .14 \\
\hline Mno $\cdots$ & .04 & .08 \\
\hline Total $\ldots . .$. & 99.02 & 98.83 \\
\hline $\mathrm{FeO} / \mathrm{MgO}-\ldots$ & 1.62 & 1.9 \\
\hline $\mathrm{Na}_{2} \mathrm{O}+\mathrm{K}_{2} \mathrm{O} \cdots \cdots$ & 6.29 & 4.68 \\
\hline$A \cdots$ & 83.1 & 46.6 \\
\hline F $\ldots$ & 10.5 & 35.3 \\
\hline$M \ldots \ldots$ & 6.5 & 18.1 \\
\hline
\end{tabular}

CIPW norms (weight percent)

\begin{tabular}{|c|c|c|}
\hline Q $\cdots$ & 37.1 & 21.0 \\
\hline or & 6.0 & 3.5 \\
\hline$a b \cdots$ & 46.2 & 37.4 \\
\hline an $\cdots$ & 6.9 & 21.5 \\
\hline ne & $\cdots$ & $\cdots$ \\
\hline 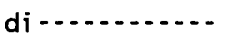 & $\cdots$ & 11.1 \\
\hline wo & $\cdots$ & $\cdots$ \\
\hline hy $\ldots \ldots \ldots$ & 1.9 & 2.1 \\
\hline ol $\ldots$ & $\cdots$ & $\cdots$ \\
\hline mt - - - & .4 & 2.2 \\
\hline il - - - & .2 & .8 \\
\hline ap $\cdots$ & .2 & .3 \\
\hline cor & 1.1 & $\cdots$ \\
\hline Norm An-.... & 11.7 & 34.4 \\
\hline Norm Ab $\ldots \ldots$ & 78.2 & 60.0 \\
\hline Norm Or-... & 10.2 & 5.6 \\
\hline
\end{tabular}

${ }^{15}$ Trondh jemite (unit $\mathrm{kt}$ ), Nelchina transect.

16 Felsite (unit Tf), Nelchina transect.
Table 2. Mole fractions of $\mathrm{Mg} /\left(\mathrm{Mg}+\mathrm{Fe}^{*}\right)$ for coexisting orthopyroxene and cummingtonite/anthophyllite from podiform hornblende gabbronorite unit (Jnpg).

[Analyses were done by electron microprobe at the University of California, Berkeley, using well-characterized standards. Techniques were discussed by Burns (1983). Fe*, total molecular Fe]

\begin{tabular}{lcc}
\hline Sample number-— & $81 \mathrm{BU} 115$ & $81 \mathrm{BU} 56$ \\
\hline Orthopyroxene- & $72.8 \pm 0.4$ & $65.0 \pm 2.8$ \\
$\begin{array}{l}\text { Cummingtonite/ } \\
\text { anthophyllite- }\end{array}$ & $79.4 \pm 1.7$ & $77.7 \pm 1.9$
\end{tabular}

